\title{
New insights into the onset and evolution of the central Apennine extensional intermontane basins based on the tectonically active L'Aquila Basin (central Italy)
}

\author{
Domenico Cosentino $^{1, \dagger}$, Riccardo Asti ${ }^{1}$, Marco Nocentini ${ }^{1}$, Elsa Gliozzi ${ }^{1}$, Tassos Kotsakis ${ }^{1}$, Massimo Mattei ${ }^{1}$, \\ Daniela Esu' ${ }^{2}$, Marco Spadi ${ }^{1}$, Marco Tallini ${ }^{3}$, Francesca Cifelli ${ }^{1}$, Massimo Pennacchioni ${ }^{4}$, Giuseppe Cavuoto ${ }^{5}$, \\ and Vincenzo Di Fiore ${ }^{5}$ \\ ${ }^{1}$ Dipartimento di Scienze, Università degli Studi Roma Tre, Largo San Leonardo Murialdo, 1, 00146 Rome, Italy \\ ${ }^{2}$ Dipartimento di Scienze della Terra, Università La Sapienza di Roma, Piazzale Aldo Moro, 5, 00185 Rome, Italy \\ ${ }^{3}$ Dipartimento di Ingegneria Civile, Edile-Architettura, Ambientale, Università degli Studi dell'Aquila, Via Giovanni Gronchi, \\ 18, 67100 L'Aquila, Italy \\ ${ }^{4}$ Dipartimento di Studi Umanistici, Università degli Studi Roma Tre, Piazza della Repubblica, 10, 00185 Rome, Italy \\ ${ }^{5}$ Istituto per l'Ambiente Marino Costiero-Consiglio Nazionale delle Ricerche, Calata Porta di Massa, 80133 Naples, Italy
}

\section{ABSTRACT}

Study of the tectonically active L'Aquila Basin offers new insights into both the creation of the extensional intermontane basins of the central Apennines of Italy and their tectono-sedimentary evolution through time. The combination of large mammal remains, ostracods, molluscs, Mousterian tools, and ${ }^{14} \mathrm{C}$ dating allows better definition of the onset and stratigraphic evolution of the L'Aquila Basin. Interpretation of a seismic reflection profile and well-log data allow evaluation of the subsurface setting of this sedimentary basin and its tectonosedimentary evolution. The occurrence of a wedge-shaped seismic unit at the base of the basin sedimentary succession defines the first phase of basin fill during a late Piacenzian-Gelasian synrift stage. Activity along the main fault of the extensional fault system responsible for the onset and subsequent development of the western sector of the L'Aquila Basin (L'AquilaScoppito subbasin) migrated from southwest to northeast, reaching the presently active Mount Pettino normal fault only in the late Pleistocene-Holocene. The onset of sedimentation in the L'Aquila Basin was synchronous with the onset in the Tiberino Basin, and so the idea that these extensional

Corresponding author: domenico.cosentino@ uniroma3.it. intermontane basins become progressively younger from the Tyrrhenian toward the Adriatic side of the central Apennines is rejected. In the northern and central Apennines, only two major syndepositional extensional domains can be recognized: a late Miocene rifting area, which includes all the late Miocene extensional basins in Tuscany, and a late Pliocene to earliest Pleistocene rifting area, which possibly includes all the intermontane basins from the Tiberino Basin to the Sulmona Basin. The different time gaps between compressional and extensional deformation at any given locality in the central Apennines could indicate a partial decoupling of processes responsible for the migration of shortening and extension toward the foreland. Diachroneity between the eastward migration of shortening in the foreland and extension in the inner part of the orogen supports the notion that the central Apennines were created as a result of a partially decoupled collision zone. Study of the onset of the central Apennine extensional intermontane basins, together with their seismic activity, indicates that the central Apennine postorogenic extensional domain represents an archive of $\sim 3$ m.y. of continued crustal extension. These findings help to refine models of the long-term extensional rate of the central Apennines, and they provide a basis for more reliable seismotectonic models for one of the most seismically active sectors of the central Mediterranean area.

\section{INTRODUCTION}

In the central Apennines of Italy, intermontane basins are mainly related to: (1) a first stage of compressional tectonics linked to the building phases of the Apennines; and (2) a second stage of later extensional tectonics related to the opening of the Tyrrhenian back-arc basin and orogenic collapse of the Apennines. During the first stage, intermontane basins were characterized by compressional tectonics and developed on top of the Apennine tectonic units as thrusttop or piggyback basins (Patacca and Scandone, 1989; Patacca et al., 1992; Cipollari and Cosentino, 1995, 1996; Cipollari et al., 1999a, 1999b; Cosentino et al., 2010), as a part of a foreland basin system (sensu DeCelles and Giles, 1996). These intermontane basins have been developing since the late Miocene at the leading edge of the central Apennine chain during its migration toward the Adriatic foreland domain. The ages of the central Apennine thrust-top basins are useful to define the main phases of the Apennine orogeny and are consistent with late Burdigalian (ca. $18 \mathrm{Ma}$ ) to late Pliocene (ca. $3 \mathrm{Ma}$ ) migration of the Apennine chain from the Tyrrhenian side toward the Adriatic side of the Italian Peninsula (Patacca and Scandone, 1989; Patacca et al., 1992, 2008; Cipollari and Cosentino, 1995, 1996; Cipollari et al., 1999a; Elter et al., 2003; Centamore and Rossi, 2009; Cosentino et al., 2010).

The subsequent nucleation of the Tyrrhenian extensional province upon the Apennine orogen, 
as a lithospheric response of the upper plate to the rollback of the subducting Adria plate (Dewey, 1988; Faccenna et al., 1996, 2001; Funiciello et al., 1999; Carminati and Doglioni, 2012), led to the continental rupture and oceanization of the Tyrrhenian area. Moreover, it enhanced the orogenic collapse of the Apennine tectonic wedge (Dewey, 1988), defining the onset of the second stage of intermontane basins in the Apennines. The extensional tectonic activity in the internal zones of the chain occurred at the same time as marginal thrusting in outer orogenic zones (Dewey, 1988; Patacca et al., 1992; Cipollari et al., 1999b). The Tyrrhenian extensional tectonics propagated toward the Adriatic foreland (Patacca et al., 1992; Cavinato and DeCelles, 1999; Cipollari et al., 1999b; Cosentino et al., 2010) following both the migration of the Apennine thrust front and the slab retreat of the subducting Adria plate. The arrival of the Tyrrhenian extensional front in different sectors of the Apennine chain gave rise to collapsing areas and the subsequent development of extensional intermontane basins, which reportedly become younger toward the Adriatic side of the central Apennines (Cavinato and DeCelles, 1999; Galadini and Messina, 2004).

Although the extensional intermontane basins of the central Apennines (Fig. 1) are among the most seismically active sectors of the central Mediterranean area (Amato et al., 1997; Bagh et al., 2007; Falcucci et al., 2011; Vannoli et al., 2012), their tectono-stratigraphic evolution is still poorly understood, and little is known about their subsurface geology. Attempts at correlating the older continental deposits among the different extensional intermontane basins have been mainly based on geomorphological observations (Bertini and Bosi, 1976; Bosi, 1989; Bosi and Messina, 1991).

Although all the extensional intermontane basins have generally similar tectonostratigraphic characteristics, the evolutionary schemes suggested by different authors are quite different. For the L'Aquila (Giaccio et al., 2012; Mancini et al., 2012; Tallini et al., 2012), Sulmona (Miccadei et al., 1998, 2002; Giaccio et al., 2009; Gori et al., 2011, 2014), Fucino (Cavinato et al., 2002), and Rieti (Cavinato, 1993) Basins, similar half-graben geometries controlled by normal faults with high seismic activity have been suggested. Nonetheless, according to the previously quoted authors, the stratigraphies of each basin are quite different. In the eastern part of the L'Aquila Basin (Paganica-San Nicandro-Castelnuovo subbasin), Giaccio et al. (2012) recognized three different synthems, whereas in the western part (the L'Aquila-Scoppito subbasin), only two main depositional phases were identified by Mancini et al. (2012). The Sulmona Basin, characterized by sedimentary infill with a total thickness of more than $400 \mathrm{~m}$ (Miccadei et al., 2002), shows a continuous deposition starting at least from the early Pleistocene (Miccadei et al., 1998; Giaccio et al., 2009). These differences in the basin stratigraphy, including any potential tectonic or climatically induced forcing of sedimentation patterns, remain unexplained.

To develop a better understanding of both the creation of the extensional intermontane basins of the central Apennines and their tectono-sedimentary evolution through time, a multidisciplinary study was carried out on the tectonically active intermontane L'AquilaScoppito subbasin (Fig. 2). In addition, by correlating the L'Aquila-Scoppito subbasin to the eastern part of the L'Aquila Basin (PaganicaSan Demetrio-Castelnuovo subbasin), as well as to other intermontane basins of central Italy (e.g., Rieti and Tiberino Basins), this work offers new insights into the onset and subsequent eastward migration of the Apennine postorogenic extensional domain.

\section{PREVIOUS STUDIES ON THE TECTONICALLY ACTIVE L'AQUILA- SCOPPITO SUBBASIN}

The L'Aquila-Scoppito subbasin is a semienclosed intermontane basin created through the pervasive extensional deformation that affected the axial zone of the Apennine chain starting in the late Pliocene-early Pleistocene (Messina et al., 2001; Centamore and Dramis, 2010; Mancini et al., 2012; Tallini et al., 2012). The L'Aquila-Scoppito subbasin is a W-E-trending half graben, bordered to the north by both the active south-dipping Scoppito-Preturo normal fault and the southwest-dipping Pettino normal fault (Vezzani et al., 2009; Tallini et al., 2012; Storti et al., 2013).

The stratigraphy of the L'Aquila-Scoppito subbasin infill, based on surface and subsurface data (Geomineraria Nazionale [GEMINA], 1963), has been studied principally by Bosi (1989), Centamore and Dramis (2010), and Mancini et al. (2012). The infill includes a Pliocene?-early Pleistocene to Holocene fluviolacustrine succession, more than $185 \mathrm{~m}$ thick (Amoroso et al., 2010), that unconformably overlies Cretaceous-Middle Miocene carbonate successions and Upper Miocene siliciclastic rocks (Vezzani and Ghisetti, 1998; Centamore and Dramis, 2010).

The oldest deposits of the L'Aquila-Scoppito subbasin fill pertain to the Colle Cantaro-Cave synthem of Centamore and Dramis (2010), which includes talus breccias and debris-flow deposits, as well as alluvial clayey-sandy conglomerates. Based on the stratigraphy of boreholes drilled in the western part of the L'AquilaScoppito subbasin, the thickness of the Colle Cantaro-Cave synthem is around $70 \mathrm{~m}$ thick (GEMINA, 1963). The transition from these basal deposits to the younger Madonna della Strada synthem is marked by a 1-3-m-thick paleosol (Centamore and Dramis, 2010), which indicates a large hiatus in the sedimentary record.

The Colle Cantaro-Cave synthem was highly deformed during the Quaternary, as indicated by tilting of bedding planes $\left(15^{\circ}-20^{\circ}\right)$, and the many outcrop-scale faults affecting the deposits. Magneto-stratigraphic analyses performed on sandy-silty deposits within this synthem display normal polarity, allowing Messina et al. (2001) to assign to them an age older than $1.77 \mathrm{Ma}$. Centamore and Dramis (2010) referred the Colle Cantaro-Cave synthem to the lower Villafranchian (Piacenzian; 3.60-2.58 Ma).

The Madonna della Strada synthem (Centamore and Dramis, 2010), which unconformably overlies the Colle Cantaro-Cave synthem, consists mainly of clayey silt, sandy silt, and sand, containing up to five intercalations of lignite. Boreholes penetrating the lignite-rich deposits indicate that they are at least $40 \mathrm{~m}$ thick (GEMINA, 1963). Thicker deposits were inferred by Tallini et al. (2012), based on interpretation of a seismic reflection profile crossing the northern part of the L'Aquila-Scoppito subbasin. There, they recognized a seismic facies up to $200 \mathrm{~m}$ thick, which boreholes revealed was composed of fine-grained lacustrine deposits referable to the Madonna della Strada synthem (Amoroso et al., 2010). This synthem is interpreted as mainly deposits of swamp and fluvio-lacustrine environments developed in a temperate and wet climate (GEMINA, 1963; Magri et al., 2010). In the upper portion of the Madonna della Strada synthem, a rich assemblage of early Pleistocene mammal remains was found (Maccagno, 1962; Magri et al., 2010; Mancini et al., 2012; Agostini et al., 2012). Centamore and Dramis (2010) referred this synthem to the upper Villafranchian (Calabrian, 1.80-0.78 Ma, and possibly Gelasian, 2.58-1.80 Ma).

A younger synthem, the Fosso di Genzano synthem (Centamore and Dramis, 2010), unconformably overlies both the Mesozoic-Tertiary bedrock of the L'Aquila-Scoppito subbasin and older synthems. Its basal strata are mainly characterized by clast-supported, structureless coarse gravels, composed mainly of limestone clasts. In this portion, a volcaniclastic horizon, up to 7-10 m thick, consisting of several ash layers with large crystals of biotite, clinopyroxene, and sanidine yielded a ${ }^{39} \mathrm{Ar} /{ }^{40} \mathrm{Ar}$ age of $520 \pm$ 5 ka (Gaeta et al., 2010). At Pagliare di Sassa, 


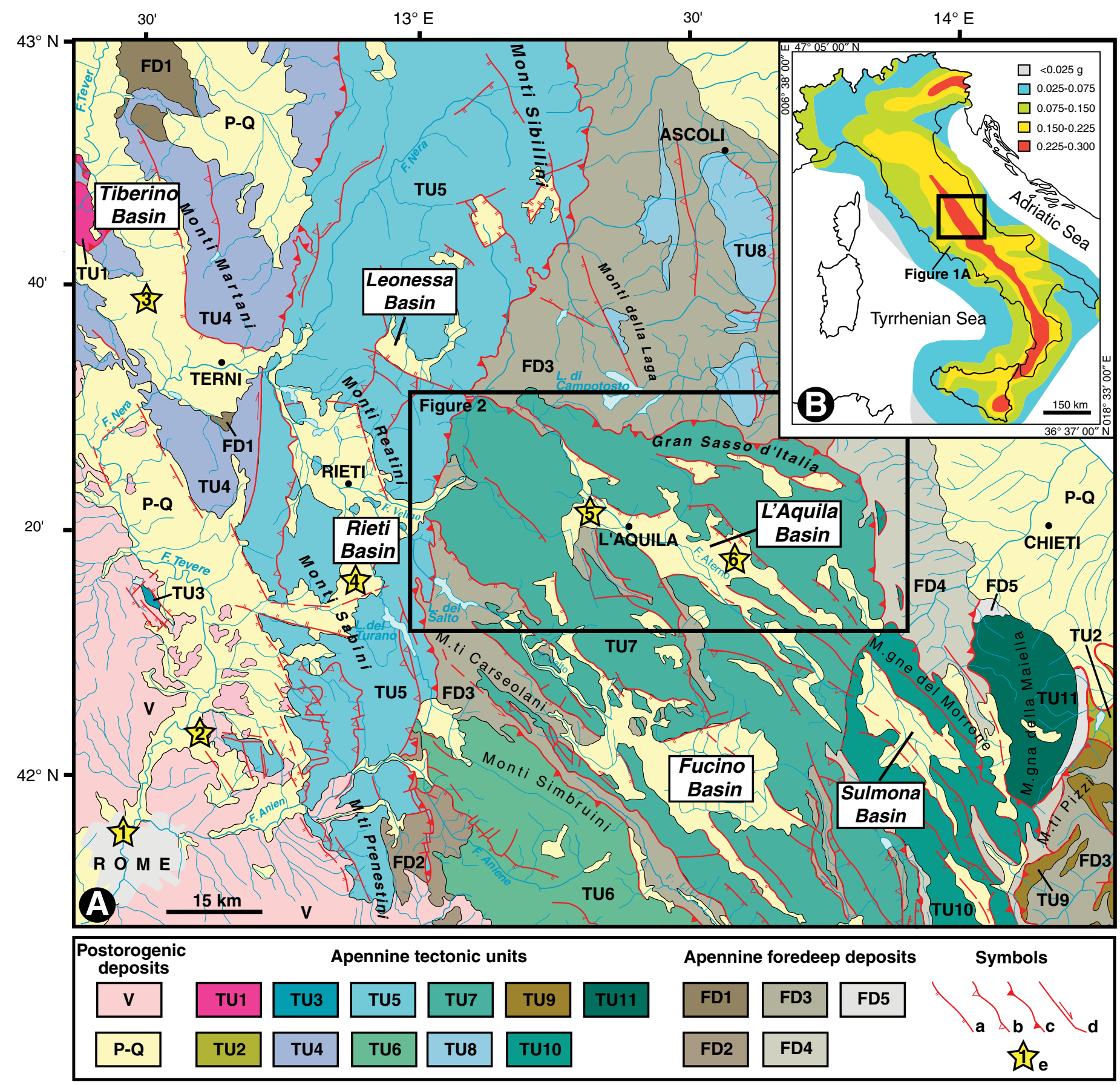

Figure 1. (A) Structural sketch of the central Apennines. The main Pliocene-Quaternary intermontane basins of the central Apennines are shown. V-Quaternary volcanic rocks; P-Q-Pliocene-Quaternary marine and continental deposits; TU1-External Ligurian unit; TU2-Sannio unit; TU3-Mount Soratte tectonic unit; TU4-Inner Umbria tectonic unit; TU5-Umbria-Marchean-Sabine tectonic unit; TU6-Simbruini-Ernici-Matese tectonic unit; TU7-Gran Sasso-Western Marsica tectonic unit; TU8-Molise tectonic unit; TU9Acquasanta-Montagnone tectonic unit; TU10_Morrone-eastern Marsica tectonic unit; TU11—Maiella tectonic unit; FD1—Burdigalian foredeep deposits; FD2_Tortonian foredeep deposits; FD3-Messinian foredeep deposits; FD4_Upper Messinian-lower Lower Pliocene foredeep deposits; FD5—upper Lower Pliocene foredeep deposits; a—normal fault; b—minor thrust; c-major thrust; d-strike-slip fault; e-location of the stratigraphic logs in Figure 13. (B) Map of the seismic hazard in Italy, showing peak ground accelerations ( $g$ ) that have a $10 \%$ chance of being exceeded in $50 \mathrm{yr}$ (Meletti and Montaldo, 2007). It is worth noting that in the central and southern Apennines, peak ground acceleration maxima correspond to extensional intermontane basins. 


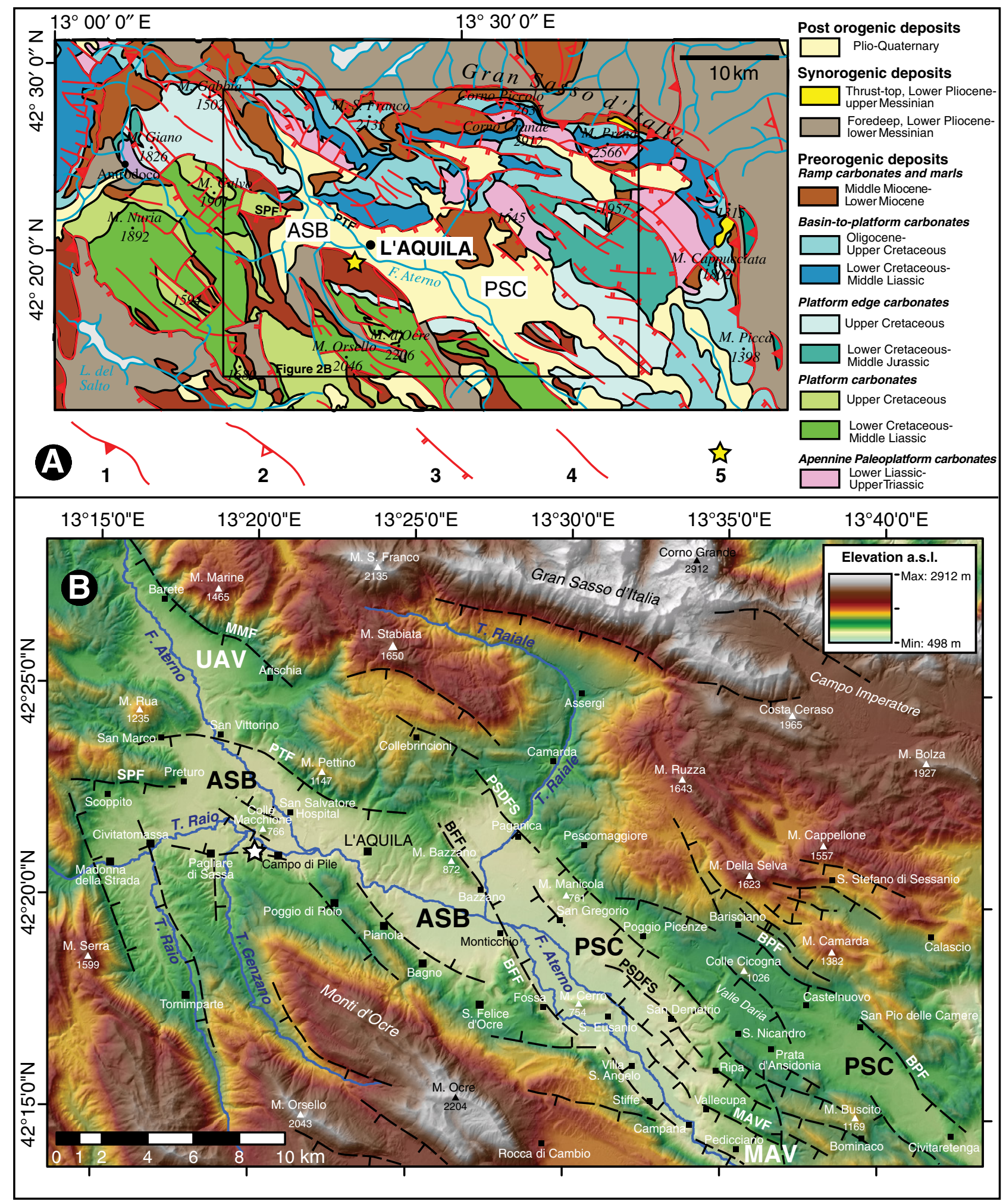

Figure 2. (A) Geological sketch map of L'Aquila intermontane basin and surrounding regions. 1—major thrust; 2-minor thrust; 3-normal fault; 4-undifferentiated fault; 5-epicenter of the 6 April 2009, Mw 6.1 earthquake. ASB-L'Aquila-Scoppito subbasin; PSC-Paganica-San Nicandro-Castelnuovo subbasin; SPF-Scoppito-Preturo normal fault; PTF-Pettino normal fault. Location of part B is shown. (B) Topography of the L'Aquila intermontane basin and surrounding regions (m a.s.l.- - meters above sea level); the major fault planes are shown by black dashed lines with tick marks on downthrown block. ASB-L'Aquila-Scoppito subbasin; PSC_Paganica-San Nicandro-Castelnuovo subbasin; UAV_-Upper Aterno Valley; MAV-Middle Aterno Valley; MAVF-Middle Aterno Valley fault; MMF-Monte Marine fault; PTF-Monte Pettino fault; SPF-Scoppito-Preturo fault; BFF-Bazzano-Fossa fault; PSDFS-Paganica-San Demetrio fault system; BPF-Barisciano-San Pio delle Camere fault. White star is the location of the BAR 20 section. 
still in the basal portion of this synthem, large and small mammal remains referable to the Galerian Mammal Age (ca. 0.7 Ma; early middle Pleistocene) were found within a normal polarity chron (Palombo et al., 2010). Up section, the synthem is dominated by alternating silty and sandy deposits, with rare thinly laminated clayey silts representing the distal portions of alluvial fans, passing laterally to floodplains.

The overlying Catignano synthem (Centamore et al., 2006; Centamore and Dramis, 2010) is characterized by terraced alluvial deposits, consisting mainly of well-rounded gravels in a sandy-silty matrix. These alluvial deposits were carved into the previous synthems. According to Centamore et al. (2006), the alluvial terrace east of Coppito (i.e., San Salvatore Hospital alluvial terrace) pertains to the Catignano synthem, which is late middle Pleistocene in age.

Finally, the Valle Majelama synthem (Centamore et al., 2006; Centamore and Dramis, 2010) consists predominantly of terraced alluvial deposits, characterized by gravel with a sandy-silty matrix, and rock debris accumulated at the foot of hills or ridges. These deposits are widespread in the L'Aquila-Scoppito subbasin, characterizing the uppermost Pleistocene cover of the basin. According to Centamore and Dramis (2010), their age is late Pleistocene.

Holocene alluvial and colluvial deposits are the youngest sediments of L'Aquila-Scoppito subbasin, related to the erosional and depositional processes that are still active in the intermontane basin.

\section{MATERIAL AND METHODS}

Geological data from surface analyses were integrated with subsurface data from deep boreholes drilled by (GEMINA, 1963) for lignite exploration and from additional shallow boreholes ( $>400$ wells) drilled in the area just after the L'Aquila 2009 earthquake (6 April 2009, Mw 6.1; Scognamiglio et al., 2010). A seismic reflection profile (Pettino 1), previously interpreted by Tallini et al. (2012), was re-examined to evaluate seismic facies within the basin.

Near the Campo di Pile industrial area, some new stratigraphic sections were exposed as a consequence of rock excavation for civil engineering use. This allowed direct examination of the stratigraphy of the basin fill (BAR 20 section), as well as collection of new large mammal remains and continental molluscs. Samples were collected from the BAR $20 \mathrm{sec}$ tion (Fig. 3) for magnetostratigraphic analyses as well as for paleontological studies of ostracods and molluscs. The latter were handpicked under a stereomicroscope from $0.125 \mathrm{~mm}$ sieved samples.

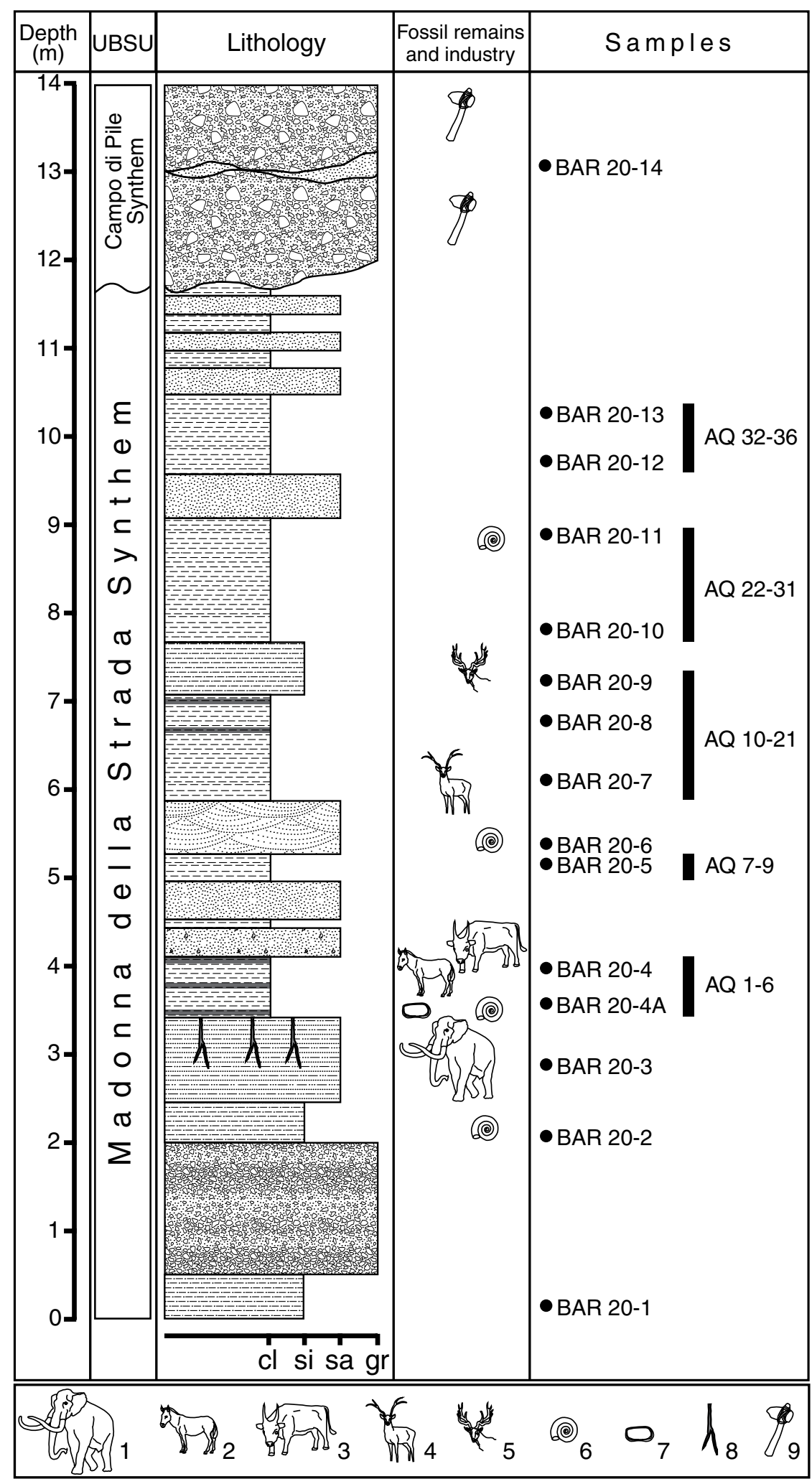

Figure 3. Stratigraphic log of the BAR 20 section $\left(42^{\circ} 21^{\prime} 09.3^{\prime \prime} \mathrm{N}, 13^{\circ} 20^{\prime} 20.5^{\prime \prime} \mathrm{E}\right)$, with locations of samples for paleontological studies (BAR) and magnetostratigraphic analyses (AQ). BAR 20-14 is the sample for ${ }^{14} \mathrm{C}$ dating. $1-$ Mammuthus meridionalis; 2-Equus sp.; 3-large bovid; 4-Axis eurygonos; 5-cfr. Praemegaceros obscurus; 6-molluses; 7-ostracods; 8-root trace; 9-Mousterian industry; cl-clay; si-silt; sa-sand; gr-gravel; UBSU—unconformity-bounded stratigraphic unit. 
For magnetostratigraphic analyses, 36 cores were drilled with an ASC 280E petrol-powered portable drill and oriented in situ using a magnetic compass. Standard cylindrical specimens were cut from each core. The natural remanent magnetization (NRM) was measured at the paleomagnetic laboratory of the Istituto Nazionale di Geofisica e Vulcanologia (INGV), Rome, Italy, using a 2-G Enterprises superconducting rock magnetometer (SRM) equipped with DCSQUID coils within a magnetically shielded room. One specimen per core was measured by means of progressive stepwise demagnetization using alternating field (AF) procedures. Stepwise AF demagnetization was carried out using a set of three orthogonal AF coils mounted inline with the SRM system, with 5-10 mT increments up to $20 \mathrm{mT}$, followed by $20 \mathrm{mT}$ steps up to $100 \mathrm{mT}$.

\section{RESULTS}

\section{Subsurface Geology}

\section{Well Logs}

Examination of more than 400 wells drilled in the study area allowed us to reconstruct the geometry of the basin fill, the variation in depth to bedrock throughout the basin, and the thickness changes of the L'Aquila-Scoppito subbasin synthems (Fig. 4). Subsurface bedrock ridges within the basin (see section $\mathrm{C}^{-} \mathrm{C}^{\prime}$ in Fig. 4) have produced marked changes of thickness and facies in the L'Aquila-Scoppito subbasin Pliocene-Quaternary fill, which reflect the intense deformation that occurred in the area during and after the onset of subsidence in the L'Aquila intermontane basin.

The Colle Cantaro-Cave synthem was intersected in almost all of the wells, except in some boreholes close to L'Aquila Hill (e.g., S46 in Fig. 4), and boreholes drilled near the Collettara ridge (e.g., S31 in Fig. 4). The maximum thickness of this synthem $(\sim 70 \mathrm{~m})$ is from wells S28 and S1, in the western part of the L'AquilaScoppito subbasin.

The Madonna della Strada synthem shows marked lateral changes of lithofacies within the basin. The boreholes from the northern and western parts of the L'Aquila-Scoppito subbasin, and those drilled in the Campo di Pile area mostly intersected fine-grained deposits (e.g., silt and silty clay), mainly deposited in marsh and swamp environments, whereas those drilled in the southern part, close to L'Aquila Hill, are mainly silty sand, sand, and gravel deposited in alluvial plain or other riverine environments. The maximum recorded thickness of the Madonna della Strada synthem is in well S46, which inter- sected $165 \mathrm{~m}$ (Fig. 4) of fine-grained deposits of alluvial plain origin.

The stratigraphic relationships among the Middle-Upper Pleistocene synthems of the L'Aquila-Scoppito subbasin basin fill are best seen in well S17 (Fig. 4), drilled close to the San Salvatore Hospital.

\section{Seismic Reflection Profile}

In the seismic reflection profile analyzed in this paper (Pettino 1), five different seismic facies were recognized. One of these is correlated with the pre-Pliocene bedrock. The other four represent different components of the L'AquilaScoppito subbasin sedimentary infill (Fig. 5).

Seismic facies $\boldsymbol{S}$. Seismic facies $\mathrm{S}$ is marked by a chaotic seismic facies, with low-amplitude, apparently parallel, discontinuous reflectors. It characterizes the lower portion of the Pettino 1 seismic reflection profile, and its margins. It is characterized by a low-resolution signal, due to weak penetration of the seismic pulse. This seismic facies is interpreted as the acoustic bedrock of the L'Aquila-Scoppito subbasin fill.

Seismic facies $R$. Seismic facies R is typically characterized by high-amplitude, discontinuous or semicontinuous reflectors. It is recognizable almost throughout the seismic reflection profile between $\sim 100$ and $\sim 1200$ m common depth point (CDP), and it shows a maximum thickness of $\sim 200 \mathrm{~ms}$. It is characterized by a highly disturbed signal, although its resolution is sufficient to define fairly continuous reflectors. These usually exhibit a divergent internal configuration, indicating wedge-shaped geometries. Locally, this seismic facies appears highly disturbed, and it can be difficult to distinguish from seismic facies S. Nonetheless, its extremely irregular lower boundary points to an erosional contact with seismic facies S. The high-amplitude and discontinuous character of this seismic facies is consistent with clastic deposits, including slopederived breccias, debris-flow deposits, and alluvial clayey-sandy conglomerates of the Colle Cantaro-Cave synthem. The wedge-shaped geometry that characterizes parts of this seismic facies, together with the structural setting of the L'Aquila-Scoppito subbasin, points to synrift clastic deposition into a tectonically controlled sedimentary basin.

Seismic facies $L$. Seismic facies L is characterized by continuous and parallel reflectors with medium to high amplitude. This facies, as well as seismic facies $\mathrm{R}$, is present along the whole seismic reflection profile. Seismic facies L has highly variable thicknesses across the Pettino 1 profile, including $\sim 300 \mathrm{~ms}$ in the southwestern area, $\sim 200 \mathrm{~ms}$ in the northeastern area, and $\sim 100 \mathrm{~ms}$ in the central area. Typically, the continuous parallel reflectors in this seismic fa- cies are horizontal, except along the southwestern margin of the Pettino 1 profile, where they appear to be dragged down along an extensional fault plane. The lower boundary, between facies $\mathrm{L}$ and $\mathrm{R}$, is highly irregular and unconformable. Based on the stratigraphy of boreholes drilled in the northern part of L'Aquila-Scoppito subbasin (GEMINA, 1963; Amoroso et al., 2010), it is possible to correlate seismic facies L with the Madonna della Strada synthem. Given the internal configuration of this seismic facies, its deposition might have occurred during a postrift stage.

Seismic facies BC. Seismic facies BC is defined by fairly continuous, low-amplitude reflectors, with parallel to irregular and chaotic geometry. Both the basal and upper boundaries of this seismic facies are highly irregular. It was recognized in the Pettino 1 profile between $\sim 200$ and $\sim 350 \mathrm{~m} \mathrm{CDP}$, at $\sim 100$ and $\sim 200 \mathrm{~ms}$. Both the stratigraphic position and the internal geometry of this seismic facies allow correlation with the chaotic breccias and megabreccias that crop out southwest of the Pettino 1 profile (Colle Macchione ridge) and near Coppito (Brecce dell' Aquila Auctorum).

Seismic facies $\boldsymbol{A D}$. Seismic facies $\mathrm{AD}$ is typically characterized by a chaotic facies, with seismic reflectors of medium to low amplitude. This facies is distributed throughout the seismic reflection profile. Its lower boundary is extremely irregular and is located at a depth between $\sim 100$ and $\sim 200 \mathrm{~ms}$. In the southwestern segment of the Pettino 1 profile (starting from $\sim 700 \mathrm{~m} \mathrm{CDP}$ ), it is possible to distinguish some continuous reflectors within the predominantly chaotic facies, whereas in the northeastern zone, the $\mathrm{AD}$ facies is characterized by more chaotic geometries. It is possible to refer this seismic facies to the youngest deposits of the L'AquilaScoppito subbasin fill, including the pediment at Mount Pettino and the Upper Pleistocene alluvial deposits of the Aterno River.

\section{Paleontology of the BAR 20 Section}

The BAR 20 section (Fig. 3) was sampled near the Campo di Pile industrial area, where new stratigraphic sections were well exposed in October 2011 as a consequence of rock excavation for industrial buildings. The section is $14 \mathrm{~m}$ thick and shows the coarse-grained alluvial deposits of the Campo di Pile synthem (Upper Pleistocene; see section "Remarks on the Stratigraphy of the L'Aquila-Scoppito Intermontane Basin"), unconformably overlying finer-grained strata of the Madonna della Strada synthem (Lower Pleistocene). This latter synthem (12 $\mathrm{m}$ thick) includes both finegrained sediments, mainly consisting of silt 


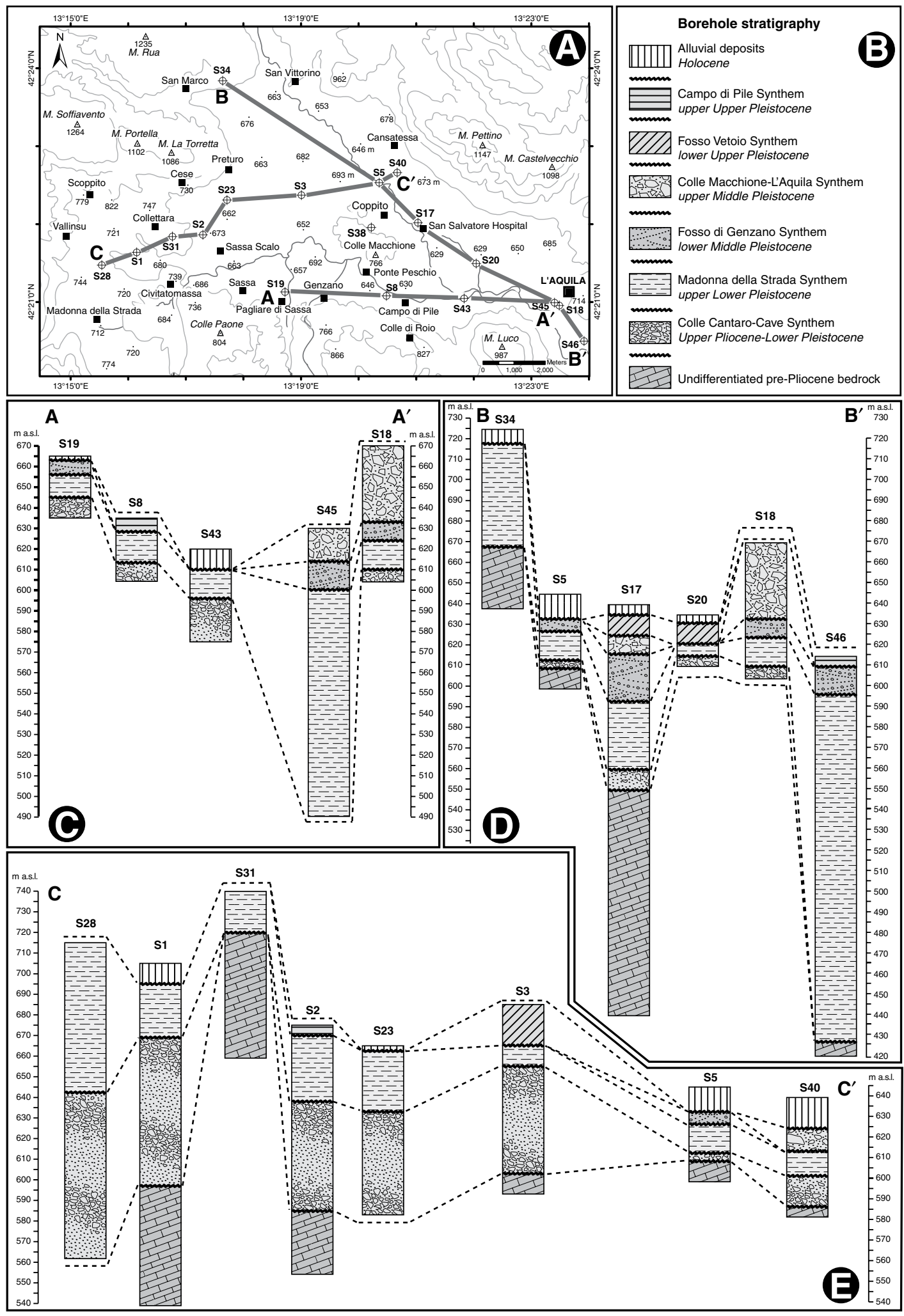

Figure 4. (A) Location map of the selected well logs from the L'Aquila-Scoppito subbasin (ASB). A-A', $B-B^{\prime}$, and C-C' correspond to the panels figured in C, D, and E. (B) Stratigraphy used in this work to correlate the selected boreholes from the L'Aquila-Scoppito subbasin ( $m$ a.s.l.- meters above sea level). (C) A-A' correlation panel of the boreholes along the southern margin of the L'Aquila-Scoppito subbasin. (D) B-B' correlation panel of the boreholes along the northern margin of the L'Aquila-Scoppito subbasin. (E) C-C' correlation panel of the boreholes from the northwestern part of the L'Aquila-Scoppito subbasin. The selected correlation panels show both the depth variation of the bedrock throughout the basin and the thickness changes of the L'Aquila-Scoppito subbasin synthems. 


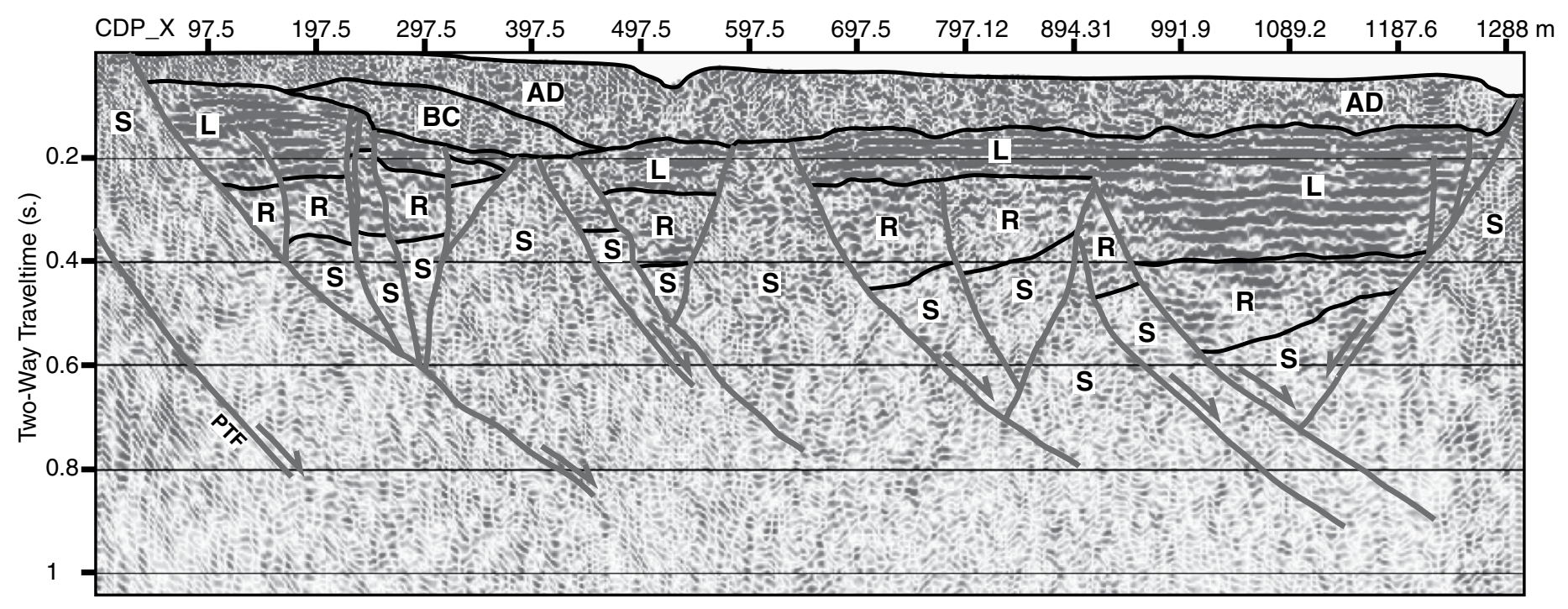

Figure 5. Interpretation of the Pettino 1 seismic reflection profile (see location in Fig. 12). The recognized seismo-stratigraphic units are: S-acoustic bedrock of the L'Aquila-Scoppito subbasin filling; R-deposits sedimented during the synrift stage (Colle Cantaro-Cave Synthem); L-deposits sedimented during the postrift stage (Madonna della Strada Synthem); BC-chaotic breccias and megabreccias (Colle Macchione-L'Aquila synthem); AD-Mount Pettino's pediment and Upper Pleistocene-Holocene alluvial deposits of the Aterno River; PTF-Mount Pettino normal fault. CDP_common depth point.

layers with root traces and clays with horizons rich in organic matter, as well as coarsegrained channelized deposits, mainly consisting of sand and gravel with cross-bedding and clast imbrication (Fig. 3). The sedimentological features of the Madonna della Strada synthem indicate an alluvial plain with palustrine wetlands (floodplains) and fluvial channels of the ancient Raio Stream.

The following subsections present results of the paleontological analyses carried out on both the samples collected from the BAR 20 section (Fig. 3) and the associated large mammal remains. A detailed description of both the ostracod assemblage and the fossil vertebrates collected in the BAR 20 section, with comments on their taxonomy, is available in GSA Data Repository. ${ }^{1}$

\section{Ostracods and Molluscs}

Fourteen samples collected from the BAR 20 section were studied for ostracod micropaleontologic analysis. The majority of samples were barren, but sample BAR 20-4A yielded a rich and well-preserved assemblage of seven spe-

${ }^{1}$ GSA Data Repository item 2017219, detailed description of the ostracod assemblage and fossil vertebrates collected in the BAR 20 section, with comments on their taxonomy, together with general information on the occurrence of Mousterian tools in Abruzzi, is available at http://www.geosociety.org/datarepository/ 2017 or by request to editing@ geosociety.org. cies belonging to six genera: Candona (Neglecandona) neglecta Sars, 1887, Pseudocandona marchica (Hartwig, 1899), Ilyocypris bradyi Sars, 1890, Eucypris dulcifrons Diebel and Pietrzeniuk, 1969, Eucypris pigra (Fischer, 1851), Potamocypris zschokkei (Kaufmann, 1900), and Paralimnocythere messanai Martens, 1992 (Fig. 6).

The autoecological characteristics of each species given by Meisch (2000) indicate that the fossil ostracod assemblage recovered in sample BAR 20-4A represents a true autochthonous thanatocoenosis, consisting of oligothermophilic (at least cold stenothermal in the case of $P$. zschokkei), rheophilic, and sometimes crenophilic species that inhabited mainly small and shallow permanent or temporary waterbodies. According to Fuhrmann et al. (1997) and Fuhrmann (2012), the fossil E. dulcifrons is typical of the cold climate assemblages from Pleistocene glacial intervals.

The silty and sandy-silty samples BAR 20-2, 20-4, 20-8, and 20-11 contained no ostracods but yielded several fragmentary specimens of pulmonate gastropods, referable to the families Planorbidae and Lymnaeidae. Notably, sample BAR 20-4A was rich in Planorbis planorbis (Linnaeus, 1758), accompanied by a few fragmentary specimens of Stagnicola sp. The abundance of $P$. planorbis, especially characteristic of shallow waterbodies liable to desiccation, is indicative of temporary or permanent shallow waterbodies (up to $1 \mathrm{~m}$ depth) with well-vegetated standing or slowly flowing waters, and temperature optimum of $19{ }^{\circ} \mathrm{C}$. Species of Stagnicola are also typical of temporary or permanent shallow water (Girod et al., 1980; Welther-Schultes, 2012). In sample BAR 20-6, only rare fragmentary specimens of terrestrial gastropods (Clausiliidae and Helicidae) were recovered.

Based on (paleo)ecological data on ostracods and molluscs, it suggested that the sedimentary succession at the BAR 20 section was deposited during a cool or cold climate interval, in a wetland with temporary swamps characterized by slow-moving waters, possibly associated with the seasonal overflow of adjacent streams.

\section{Large Mammals}

The remains of fossil vertebrates collected in the BAR 20 section consist of a horse molar, a fragment of a maxillary bone bearing two molars of a small deer, the proximal part of the radius of a large deer, and part of the diaphysis of a long bone of an unidentified medium/smallsized mammal (Fig. 7). All the material will be stored at the Soprintendenza per i Beni Archeologici dell' Abruzzo, Chieti, Italy.

The small-sized cervid classified as "Axis" eurygonos covers a long time span, from the Farneta Faunal Unit (FU; ca. 1.6-1.4 Ma) to the end of the Galerian Mammal Age (ca. $0.45 \mathrm{Ma}$; Mancini et al., 2012). If the affinity of our equid remains are affiliated with Equus suessenbornensis, this implies a time span from the Pirro Nord FU (ca. 1.4-1.2 Ma; and possibly from 


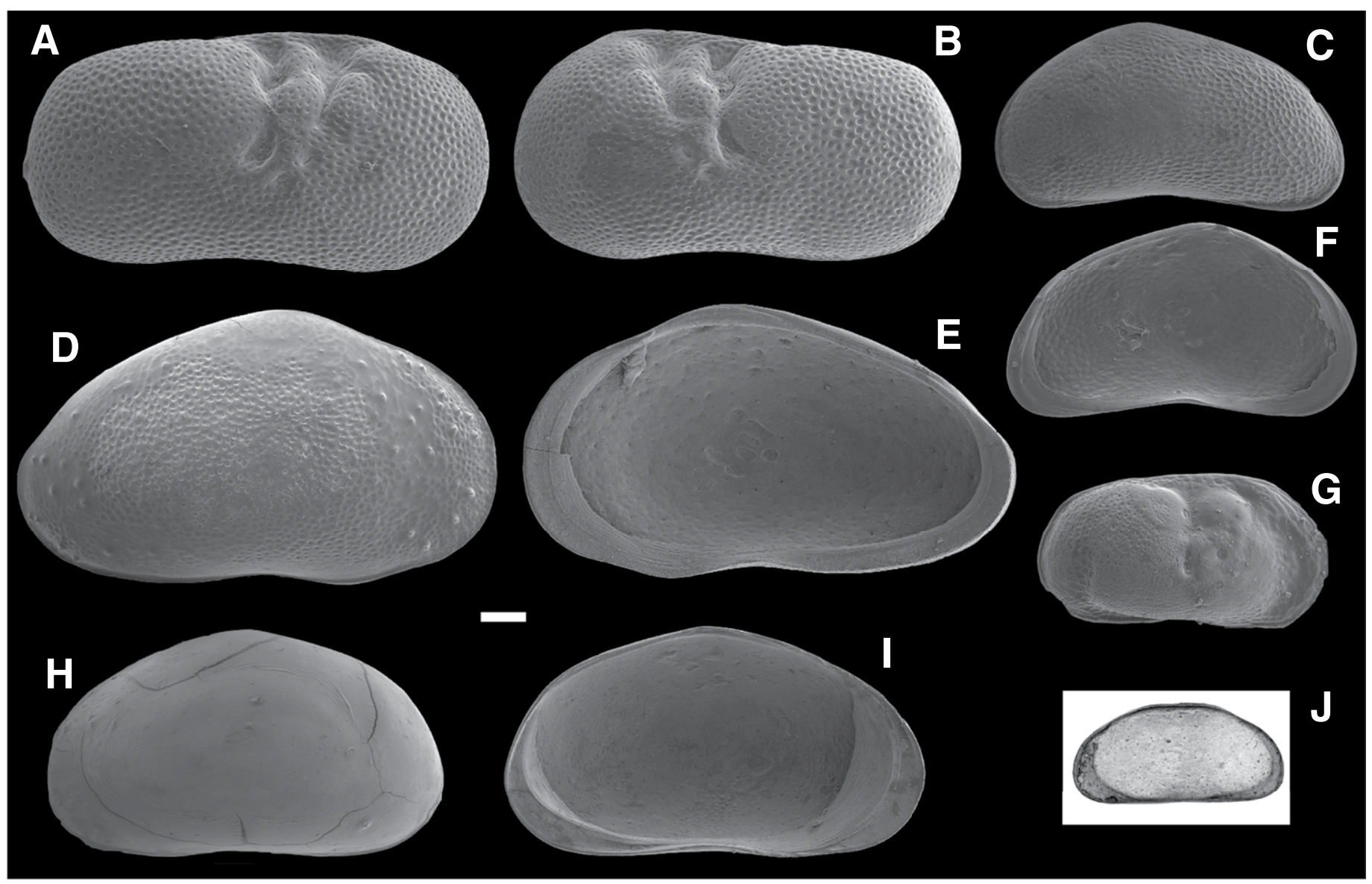

Figure 6. Scanning electron microscope (SEM) and transmitted light photos of the ostracod assemblage from (A-I) sample BAR 204A and (J) sample AQ3. (A-B) Ilyocypris bradyi Sars, 1890, where A shows right valve and B shows left valve in lateral outer view; (C, F) Potamocypris zschokkei (Kaufmann, 1900), showing lateral outer view of left valve in $C$ and inner view of left valve in $F$; (D-E) Eucypris dulcifrons Diebel and Pietrzeniuk, 1969, where right valve in D is lateral outer view and E is inner view; (G) Paralimnocythere messanai Martens, 1992, showing right valve in lateral outer view; (H-I) Eucypris pigra (Fischer, 1851), where left valve in $\mathrm{H}$ is lateral outer view and I is inner view; (J) Mixtacandona stammeri (Klie, 1938), showing left valve in lateral outer view (transmitted light). White bar corresponds to $0.1 \mathrm{~mm}$.

the Farneta FU) to the Isernia FU (ca. 0.7$0.55 \mathrm{Ma}$; Alberdi and Palombo, 2013). For the large-sized cervid, two similar chronological distributions are possible: If it is attributed to Arvernoceros giulii, this species (and the genus) is reported only from two Italian localities (Selvella and Santarelli quarry) assigned to the Farneta FU (ca. 1.6-1.4 Ma) and Pirro Nord FU (ca. 1.4-1.2 Ma), respectively (Petronio and Pandolfi, 2011). This species is also present in sites of more recent age in Germany and France(?) (Kahlke, 1997; Croitor, 2009). If the large-sized cervid remains are attributed to Praemegaceros obscurus, this species spans from the Farneta FU to Pirro Nord FU (ca. 1.6-1.2 Ma) in the Italian Peninsula (Abbazzi, 2004). Elsewhere, Croitor (2006) reported a time span from 1.4 Ma to 1.2/1.0 Ma for the total chronological distribution of the species in Europe and the Near East. Recently, the FUs of Farneta and Pirro Nord have been considered as equivalent by Siori et al. (2014). In summary, from a paleontological perspective, the small assemblage from the BAR 20 section (with the addition of Mammuthus meridionalis; Agostini et al., 2012) belongs to the Pirro Nord FU (ca. 1.4-1.2 Ma), although a slightly younger age (still older than Colle Curti FU, ca. 1.1$0.9 \mathrm{Ma}$ ) cannot be ruled out.

\section{Paleo-ethnology}

In the upper part of the BAR 20 section (Fig. 3) and at other localities close to Ponte Peschio, some lithics and bone artifacts have been found within the sandy matrix of alluvial deposits related to the Campo di Pile synthem (see section "Remarks on the Stratigraphy of the L'Aquila-Scoppito Intermontane Basin"). The abundant lithic material collected is made from fine-quality chert, mainly red, in the form of small and smooth lithic tools (Mousterian industry). The principal characteristic of the flake shown in Figure 8 is the presence of a number of intersecting flake scars on the upper surface that represent the visible remains of an earlier trimming of the core (Levalloisian core). The margins of the flake have fractures possibly related to transport in a rocky environment.

The ${ }^{14} \mathrm{C}$ dating of carbonized plant remains within the Campo di Pile synthem gives a $2 \sigma$ age of 41,854-40,464 calendar yr B.P., which allows us to correlate the Mousterian industry 

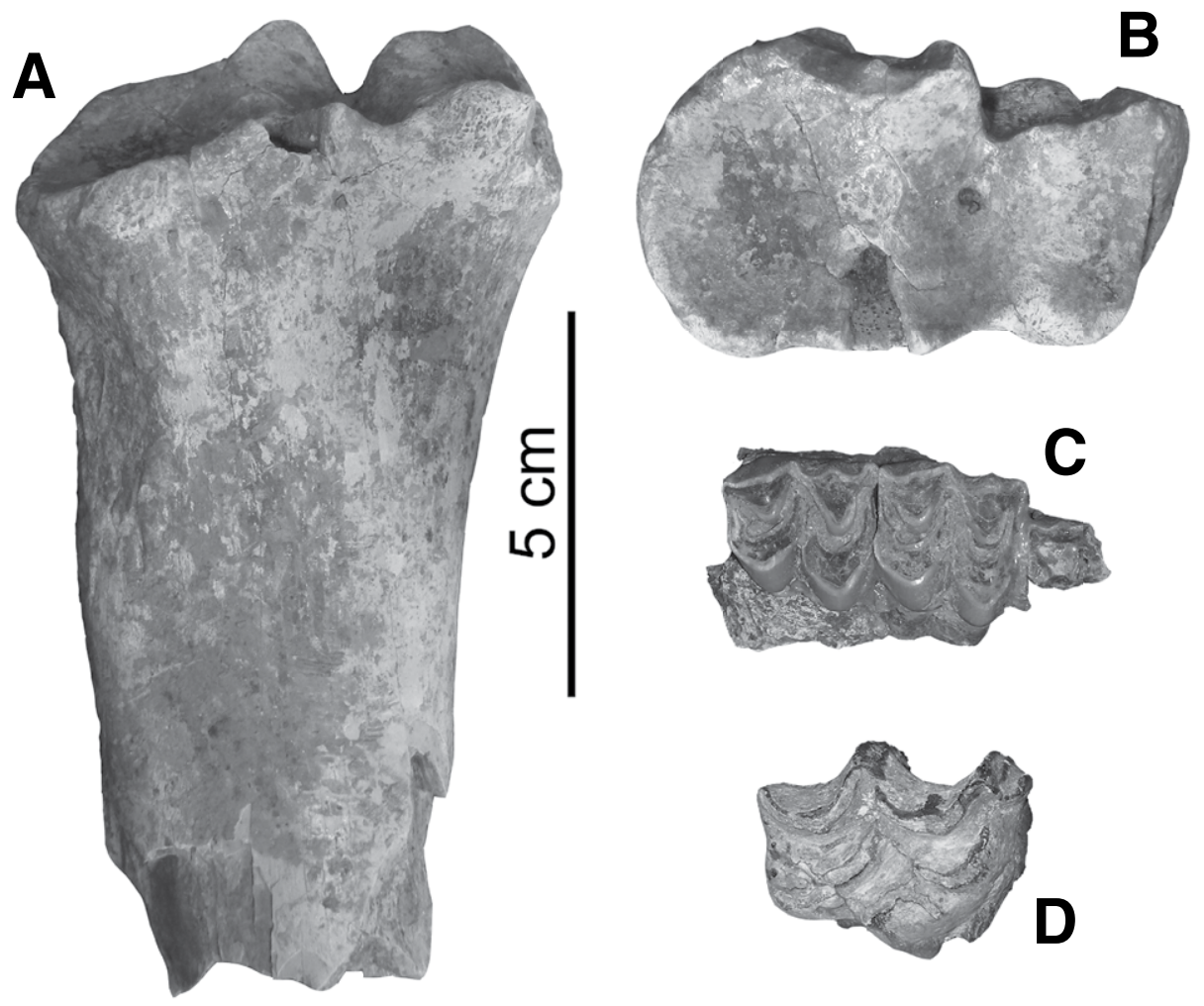

Figure 7. Large mammal remains recovered within the Madonna della Strada synthem at BAR 20 section. (A) cfr. Praemegaceros obscurus vel Arvernoceros giulii, left radius, proximal fragment, anterior view; (B) the same, proximal articular face view; (C) "Axis" eurygonos, M1, M2, and a small fragment of M3, fragment of left maxillary (the teeth are slightly displaced); (D) Equus sp., left M3.

of the Campo di Pile synthem to marine oxygen isotope stage (MIS) 3 (upper late Pleistocene). General information on the occurrence of Mousterian tools in Abruzzi is provided in the GSA Data Repository (see footnote 1).
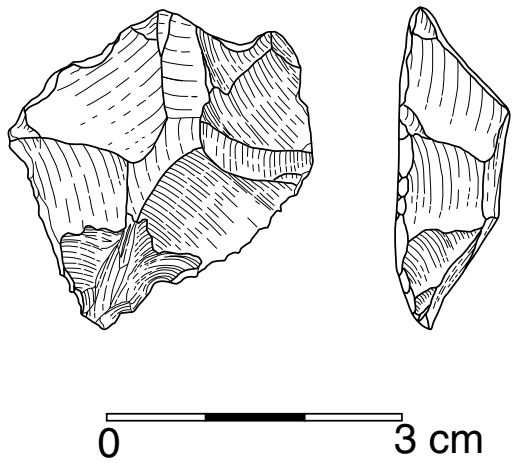

Figure 8. Drawing of one of the flakes discovered within the Campo di Pile synthem (BAR 20 section), in dorsal (left) and lateral (right) view.

\section{Paleomagnetic Results}

Some of the samples examined from the BAR 20 section (Fig. 3) were too weakly magnetized (NRM values of $\sim 160 \times 10^{-6} \mathrm{~A} / \mathrm{m}$ ) to allow for reliable complete stepwise demagnetization, or they gave unstable directions during stepwise demagnetization (Fig. 9A). Other samples had NRM intensities between $250 \times 10^{-6}$ and $850 \times$ $10^{-2} \mathrm{~A} / \mathrm{m}$. Demagnetization diagrams indicate stable paleomagnetic behavior in $53 \%$ of the samples, with demagnetization vectors aligned along linear paths directed toward the origin of vector component diagrams, after removal of a viscous low-coercivity remanence component at 5-10 $\mathrm{mT}$ up to $60-80 \mathrm{mT}$ (Figs. 9B and $9 \mathrm{C}$ ). These samples were characterized by the presence of low-coercivity minerals and do not appear to have acquired any gyromagnetic remanent magnetization (GRM). This excludes the presence of significant amounts of greigite and suggests that magnetite is the main magnetic carrier.

A least-square analysis (Kirschvink, 1980) was applied to determine characteristic rema- nent magnetization (ChRM) directions for these samples. The site-mean paleomagnetic direction was calculated using Fisher (1953) statistics. In all 19 samples, the ChRM component had a normal polarity, and the overall mean direction of in situ coordinates was declination $=20.6{ }^{\circ} \mathrm{C}$, inclination $=62.6^{\circ} \mathrm{C}, k=13.1, \alpha 95=9.6^{\circ}$, whereas in tilt-corrected coordinates, the mean direction was declination $=27.1{ }^{\circ} \mathrm{C}$, inclination $=$ $71.6^{\circ} \mathrm{C}, k=13.1, \alpha 95=9.6^{\circ}$ (Fig. 10).

Given the gentle inclination angle of the stratigraphic section and the absence of marked lateral changes in bedding attitude, it was not possible to undertake a reliable fold test to investigate the age of any isolated magnetic component with respect to the bedding tilt. However, whereas the mean paleomagnetic direction for in situ coordinates is close to the expected Geomagnetic Axial Dipole (GAD) field direction for the sampling locality (declination $=0^{\circ}$, inclination $=61^{\circ}$ ), the mean paleomagnetic direction in tilt-corrected coordinates shows an inclination value of $72^{\circ}$, which is significantly higher than the expected inclination for the sampling site. These observations cast considerable doubt on the primary origin of the normal polarity ChRM isolated in these samples, and they strongly suggest that the ChRM is related to a secondary magnetic overprint that happened after bedding tilt in magnetitebearing samples, as reported for other Tertiary sections in the Mediterranean area (Lucifora et al., 2012).

\section{Remarks on the Stratigraphy of the L'Aquila-Scoppito Intermontane Basin}

This section provides new data and concepts for revising the stratigraphy of the western part of the L'Aquila Basin (Fig. 11), based on new field observations of the synthems proposed by Centamore and Dramis (2010), as well descriptions of newly defined synthems in the L'Aquila-Scoppito intermontane basin.

\section{Colle Cantaro-Cave Synthem}

The Colle Cantaro-Cave synthem represents the earliest deposits of the L'Aquila-Scoppito subbasin. It is present throughout the intermontane basin at the base of the basin-filling succession, and it crops out locally along the western margin of the subbasin (Centamore and Dramis, 2010). Based on re-interpretation of the Pettino 1 seismic reflection profile (Fig. 5), this synthem appears to have been deposited during an extensional (synrift) stage, when the activity of normal faults at the basin margins controlled changes in the accommodation space. Thus, its age is crucial for defining the onset of the extension responsible for the development 

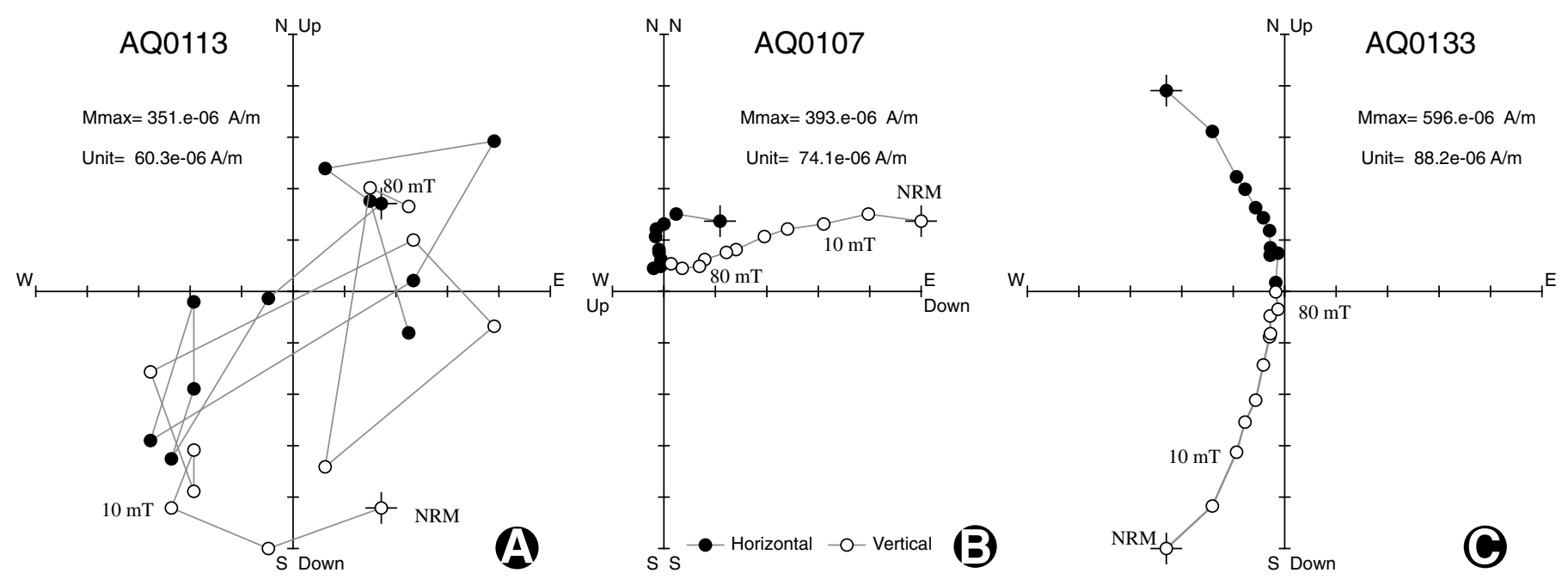

Figure 9. Orthogonal vector diagrams for the progressive alternating field demagnetization (AF) of representative samples. Demagnetization step values are in mT. Open and solid symbols represent projection on the vertical and horizontal planes, respectively. The AF demagnetization shows scatter direction of magnetization (A) and linear decay toward the origin, which allow us to isolate the characteristic remanent magnetization $(\mathrm{ChRM})(\mathrm{B}, \mathrm{C})$. NRM-natural remanent magnetization.

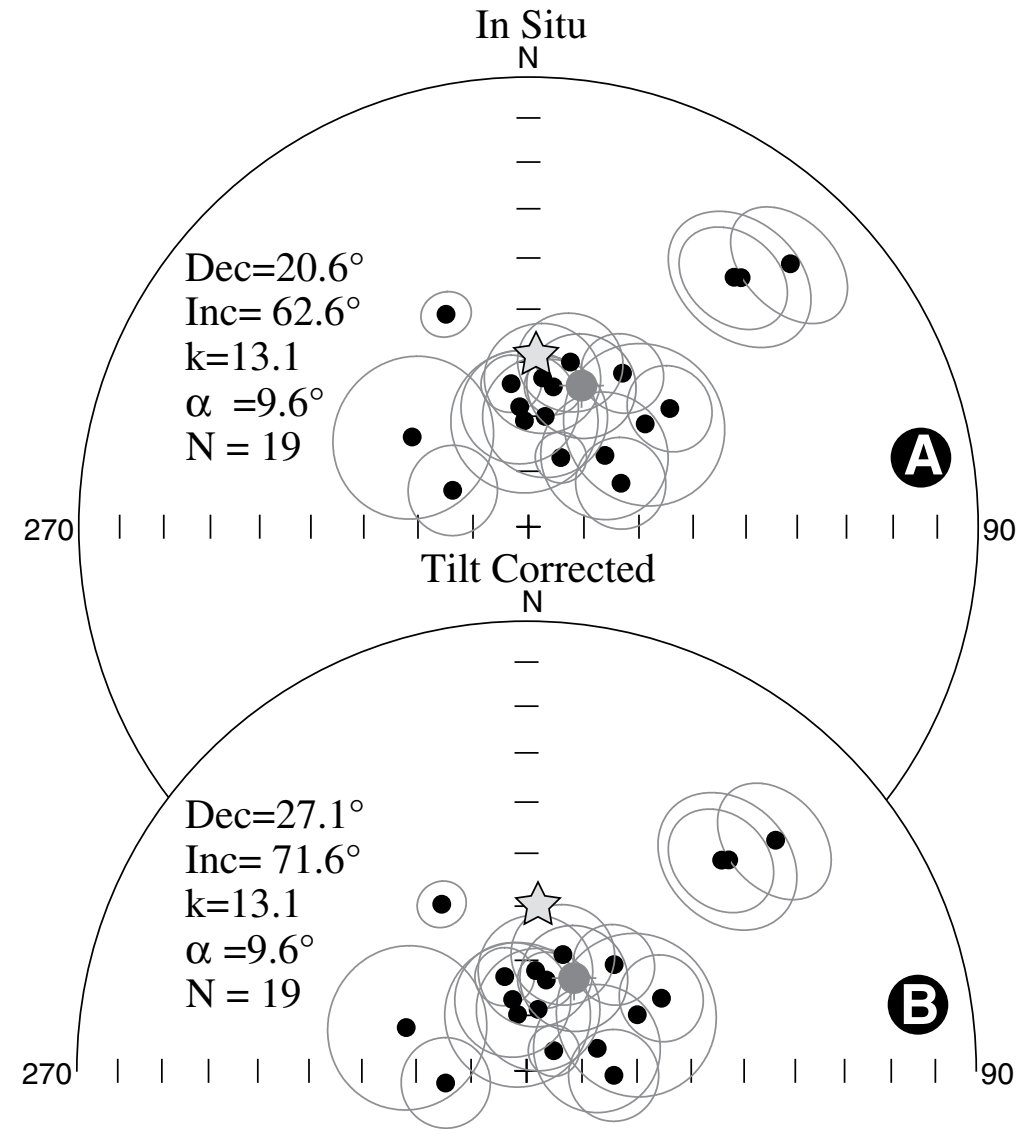

Figure 10. Equal-area projection of sample characteristic remanent magnetization (ChRM) directions (the $95 \%$ confidence ellipse is indicated) in (A) in situ and (B) tilt-corrected coordinates. Gray dot and ellipse indicate the mean paleomagnetic direction and the $95 \%$ confidence ellipse for the analyzed samples, respectively. Star shows the expected geomagnetic axial dipole (GAD) field direction for the sample site locality. of the L'Aquila-Scoppito intermontane subbasin. Unfortunately, there are no direct data from the Colle Cantaro-Cave synthem to constrain its age. However, a possible late PiacenzianGelasian age for this synthem is suggested (ca. 3.0-2.0 Ma).

\section{Madonna della Strada Synthem}

Interpretation of the Pettino 1 seismic reflection profile (Fig. 5, seismic unit L) points to a postrift stage for the deposition of this synthem. Accordingly, the unconformity surface at the base of the synthem should correspond to the breakup unconformity that separates the synrift stage of the Colle Cantaro-Cave synthem from the postrift stage of the Madonna della Strada synthem. This interpretation is consistent with the occurrence of a 1-3-m-thick paleosol that, according to Centamore and Dramis (2010), separates these two synthems. Based on previous and new large mammal findings, the age of the Madonna della Strada synthem is well defined as early Pleistocene (Calabrian: ca. 1.70-1.15 Ma).

\section{Fosso di Genzano Synthem}

The Pagliare di Sassa succession (Palombo et al., 2010) pertains to the Fosso di Genzano synthem of Centamore and Dramis (2010). Considering both the chronological constraints from large and small mammals at the Pagliare di Sassa site and ${ }^{39} \mathrm{Ar} /{ }^{40} \mathrm{Ar}$ dating of ash layers (Gaeta et al., 2010), the Fosso di Genzano synthem can be referred to the lower Middle Pleistocene (ca. 0.72-0.40 Ma). According to Palombo et al. (2010), paleomagnetic data from the Pagliare di 


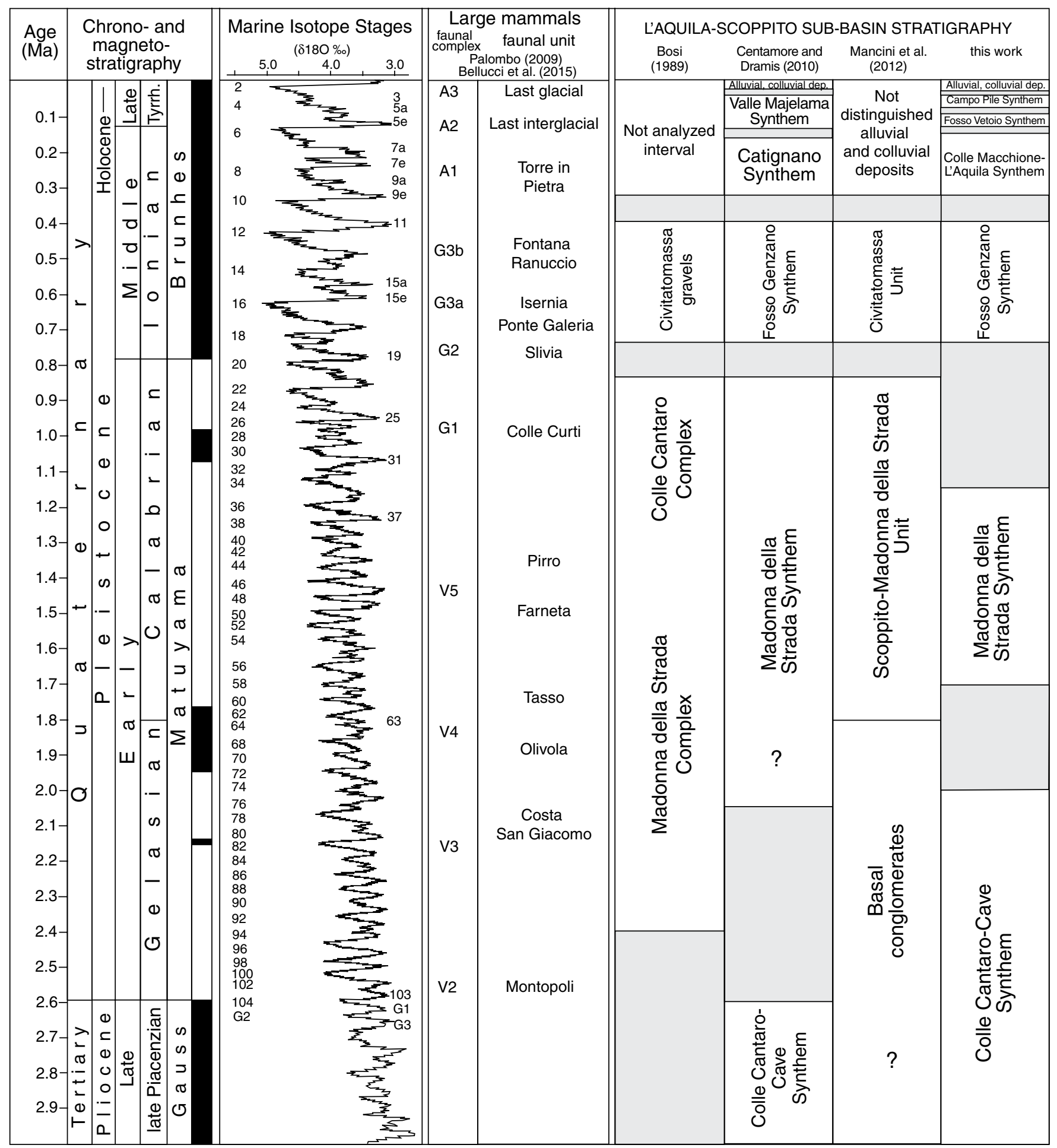

Figure 11. Quaternary stratigraphy of the L'Aquila-Scoppito subbasin (ASB) according to different authors. Centamore and Dramis (2010) considered the Colle Cantaro-Cave synthem, at the base of the L'Aquila-Scoppito subbasin fill, as lower Villafranchian (Piacenzian). In Centamore and Dramis (2010) and Mancini et al. (2012), the question mark indicates a possible extension of the respective synthem or stratigraphic unit to the Gelasian (Madonna della Strada synthem) or the Piacenzian (Basal Conglomerates). In this work, alluvial and colluvial deposits contain the Ponte Peschio synthem. 
Sassa succession support continuous deposition from the late early Pleistocene to early middle Pleistocene. However, based on the sequence of unconformity-bounded stratigraphic units recognized within the L'Aquila-Scoppito subbasin fill (Centamore and Dramis, 2010; Mancini et al., 2012; this paper), this conclusion is open to challenge. The marshy sediments of the Pagliare di Sassa core, between -30 to $-24.5 \mathrm{~m}$, are better referred to the Madonna della Strada synthem, such that the oxidized surface at $-24.5 \mathrm{~m}$ (i.e., the exposure surface in Palombo et al., 2010) corresponds to the erosional surface at the unconformable boundary between the Madonna della Strada synthem and the Fosso di Genzano synthem.

\section{Colle Macchione-L'Aquila Synthem}

The Colle Macchione-L'Aquila synthem unconformably overlies older Quaternary synthems and Mesozoic and Tertiary bedrocks (Fig. 12). It consists of breccias and megabreccias with highly heterometric, poorly rounded carbonate blocks that are mostly angular to subangular in shape (Brecce dell'Aquila Auctorum). These carbonate breccias show different textures and sedimentological characteristics. They can be characterized as clast-supported open-work breccias to matrix-supported breccias, usually well cemented but sometimes also unconsolidated, and they can be both massive and stratified. Carbonate clasts are mainly from the Mesozoic-Tertiary slope-to-basin transitional facies (e.g., breccias deposits from L'Aquila City hill). Source areas include the Gran Sasso Chain, and the cataclastic rocks of Mesozoic carbonate (e.g., breccias from Colle Macchione ridge) derived from the active extensional fault zone at the base of the southern slope of Mount Pettino. The sedimentological characteristics of these carbonate breccias point to air-lubricated inertial granular flows (sturzstrom, sensu Hsü, 1975; Pierson and Costa, 1987) produced by the southern slope of the mountain chains at the northern margin of L'Aquila-Scoppito subbasin, possibly during a late middle Pleistocene arid event. The Colle Macchione-L'Aquila synthem includes carbonate silt deposits that contain a monospecific ostracod fauna consisting of Mixtacandona stammeri (Klie, 1938) (sample AQ3 in Fig. 6J here), which are typical of interstitial waters. Those carbonate silts are interlayered with the carbonate breccias of this synthem at the eastern margin of L'Aquila City, pointing to large debris avalanches (sturzstrom, sensu Hsü, 1975; Pierson and Costa, 1987) settling in a fluvio-lacustrine environment at the base of the mountain slope bordering the northern margin of L'Aquila-Scoppito subbasin.
The age of the Colle Macchione-L'Aquila synthem is not well constrained, although the breccias are generally referred to a middle Pleistocene age (Demangeot, 1965; Bosi et al., 2003). A possible late middle Pleistocene age (ca. $0.33-0.14 \mathrm{Ma}$ ) is supported by the stratigraphy of the Colle Macchione ridge and the age of the overlying alluvial deposits of the Fosso Vetoio synthem. At Colle Macchione, the Colle Macchione-L'Aquila synthem unconformably overlies fine- to coarse-grained cross-stratified sands and laminated sandy silts, with intercalated thin layers of well-rounded, fine gravels attributed to the Fosso di Genzano synthem. In addition, in the vicinity of San Salvatore Hospital, alluvial deposits of the lower Upper Pleistocene Fosso Vetoio synthem unconformably overlie breccias of the Colle Macchione-L'Aquila synthem. For these reasons, the Colle MacchioneL'Aquila synthem is considered to be younger than the early middle Pleistocene (Fosso di Genzano synthem) and older than the early late Pleistocene (Fosso Vetoio Synthem, which represents upper Middle Pleistocene strata).

\section{Fosso Vetoio Synthem}

The Fosso Vetoio synthem consists of rounded gravel, with abundant coarse sandy matrix, and rare silty sandy lenses. Pebbles are mainly from carbonates and typically occur as channelized deposits. Above the gravel deposits, there is a succession of rust-colored cross-stratified sand and yellow silt, covered by grayish coarse sand and silt, rich in volcanic minerals. The synthem reflects deposition in a braided fluvial system active during the late Pleistocene in the L'Aquila-Scoppito subbasin. A well-preserved alluvial terrace in the area of San Salvatore Hospital shows an abandonment surface at around $640 \mathrm{~m}$ above sea level, $\sim 20-25 \mathrm{~m}$ above the present thalweg of the Aterno River. An early late Pleistocene age for the Fosso Vetoio synthem is suggested by the morpho-stratigraphical relationship between this unit and the younger Campo di Pile synthem, which in turn is well constrained by ${ }^{14} \mathrm{C}$ dating.

\section{Campo di Pile Synthem}

The Campo di Pile synthem is mainly composed of matrix-supported, well-rounded gravels in a silty sandy matrix. The clasts are predominantly carbonates and more rarely bauxites, suggesting source areas along the southern and western margins of the L'Aquila-Scoppito subbasin. The Campo di Pile synthem is interpreted as alluvial deposits of an eastward-draining river system. It defines a valley-confined strath terrace with its depositional top at 10-13 m above the present thalweg. This synthem cuts into the Fosso Vetoio synthem and as well as both Lower Pleistocene strata and pre-Pliocene bedrock. The thickness of this synthem is usually less than $5 \mathrm{~m}$.

The age of the Campo di Pile synthem is well constrained by ${ }^{14} \mathrm{C}$ dating of carbonized plant remains from a section close to Ponte Peschio, which gave a $2 \sigma$ age of $41,854-40,464$ cal yr B.P., allowing correlation with MIS 3 (late Pleistocene). This age is in agreement with remains of a lithic industry of Mousterian age (late middle Paleolithic) in the gravels.

\section{Ponte Peschio Synthem}

The Ponte Peschio synthem is defined by a thin alluvial cover on a few small remnants of the youngest late Pleistocene fluvial terraces within the L'Aquila-Scoppito subbasin (Fig. 12). The depositional top of the Ponte Peschio synthem lies 5-7 $\mathrm{m}$ above both the Raio and the Aterno thalwegs. Near the San Salvatore Hospital, it is embedded in the Fosso Vetoio synthem and carved into the Colle Macchione-L'Aquila synthem, while at Ponte Peschio, it cuts into the Campo di Pile synthem and directly into pre-Pliocene bedrock. There, the Ponte Peschio synthem may be interpreted as a strath terrace.

\section{Aterno Synthem}

This is the youngest synthem within the L'Aquila-Scoppito intermontane subbasin. Its base cuts into the previous synthems, and in places, it is carved directly into underlying prePliocene bedrock. This synthem includes all the Holocene alluvial and colluvial deposits of the L'Aquila-Scoppito subbasin, which are related to the erosional and depositional processes that are still active in the intermontane basin.

\section{TECTONO-STRATIGRAPHIC EVOLUTION OF L'AQUILA BASIN AND SURROUNDING REGIONS}

\section{Cessation of Shortening and Initiation of Deposition in L'Aquila Extensional Intermontane Basin}

The absence of outcrops of the oldest sedimentary fill of most extensional intermontane basins in central Italy, together with the scarcity of biochronologically and/or geochronologically well-constrained stratigraphic successions, has hindered attempts to define the timing of their initial development. However, a maximum age for the creation of the L'Aquila-Scoppito subbasin can be inferred from the age of the latest shortening event that affected the area, which was responsible for the onset of intermontane compressional basins (e.g., Conglomerati di Rigopiano) in the early Pliocene (top Zanclean; Ghisetti and Vezzani, 1986; Patacca 


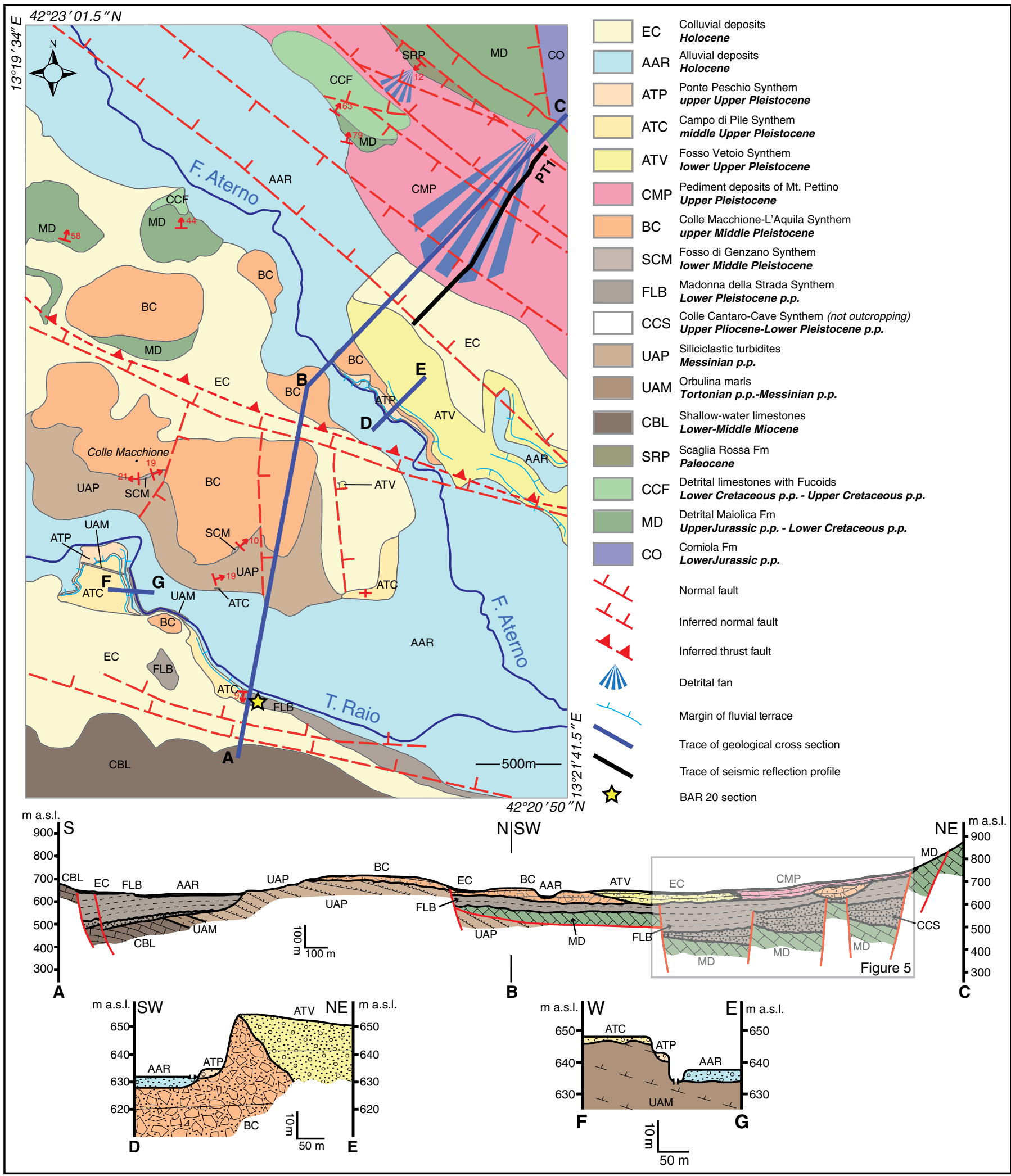

Figure 12. Geology of the L'Aquila-Scoppito subbasin. PT1-trace of the Pettino 1 seismic reflection profile. In the A-B-C cross section, the position of the PT1 seismic reflection profile (Fig. 5) is also shown; m a.s.l.—meters above sea level; p.p.-pro parte. 
et al., 1992; Ghisetti et al., 1993; Centamore et al., 2006). According to these data, the maximum age for the onset of extension in the Gran Sasso-L'Aquila area is the Zanclean-Piacenzian transition (ca. 3.59 Ma).

According to Giaccio et al. (2012), the earliest stage of basin development in the eastern part of the L'Aquila Basin (Paganica-San Nicandro-Castelnuovo subbasin) is as old as 2 Ma (Gelasian, lowermost early Pleistocene), whereas Cavinato and DeCelles (1999) suggested a Selinuntian age (early Pleistocene,
$<1.8 \mathrm{Ma}$ ) for the onset of extension. In the western part of L'Aquila Basin (L'Aquila-Scoppito subbasin), the Basal Conglomerates (Mancini et al., 2012), corresponding to the basal infilling of L'Aquila-Scoppito subbasin (Colle CantaroCave synthem; Centamore and Dramis, 2010), were attributed by Mancini et al. (2012) to the lowermost Lower Pleistocene (Gelasian), and tentatively to the Upper Pliocene (Piacenzian). Centamore and Dramis (2010) tentatively correlated the Colle Cantaro-Cave synthem with the lower Villafranchian Mammal Age, that is, Up- per Pliocene (Piacenzian; 3.59-2.58 Ma). These contrasting ages demonstrate that the timing of the L'Aquila basal basin filling is still a matter of debate.

To reduce these uncertainties, an attempt was made (Fig. 13) to correlate the stratigraphy and tectonic setting of the L'Aquila Basin with those of other intermontane basins of the central Apennines (Tiberino Basin-Basilici, 1995, 1997; Rieti Basin-Barisone et al., 2014; Cosentino et al., 2014) and suggest their possible relation to Pliocene-Quaternary relative

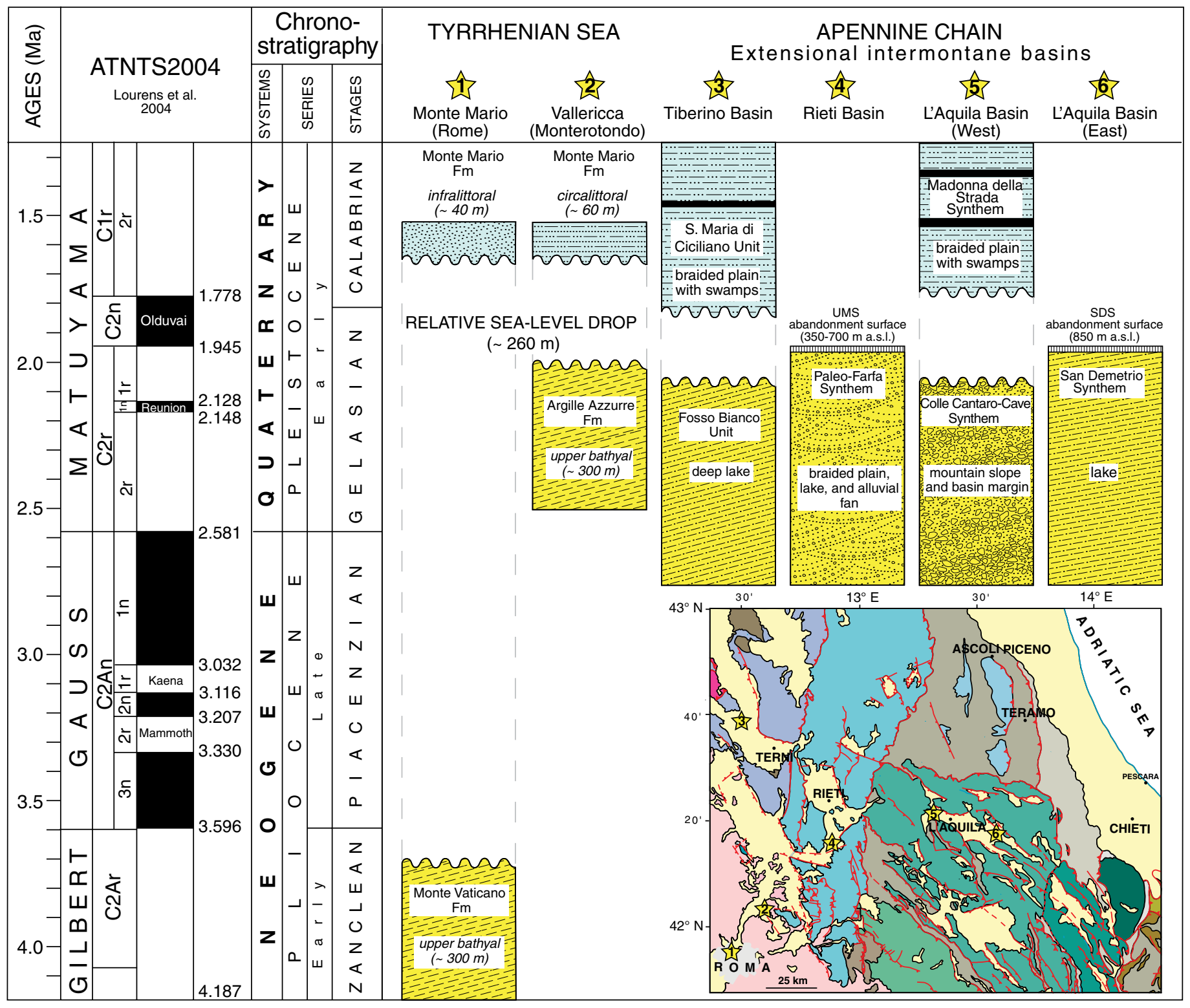

Figure 13. Correlation panel among different Pliocene-early Pleistocene stratigraphic sections from the Roman area and the main intermontane basins discussed in the text. The relative sea-level drop of $\sim 260 \mathrm{~m}$ at the Gelasian-Calabrian transition, mainly related to uplift, correlates the major stratigraphic discontinuities detected both in the Roman area and in the intermontane basins of the central Apennines. UMS-Monteleone Sabino unit; SDS—San Demetrio synthem; $\mathbf{m}$ a.s.l.-meters above sea level. See Figure 1 for the legend of the location map. ATNTS2004-Astronomical Tuned Neogene Time Scale 2004. 
sea-level changes of the Tyrrhenian Sea and the Pliocene-Quaternary succession of Rome and neighboring areas (Cosentino and Fubelli, 2008; Cosentino et al., 2009).

In the eastern part of the L'Aquila Basin (the Paganica-San Nicandro-Castelnuovo subbasin), the oldest deposits of the Lower Paganica-San Nicandro-Castelnuovo subbasin synthem (2.0-0.78 Ma; Giaccio et al., 2012), which are associated with a lake environment (Limi di San Nicandro Auctorum, San Nicandro Formation-Bertini and Bosi, 1993; San Demetrio synthem-Spadi et al., 2016), contain ostracod assemblages characterized by the presence of Caspiocypris spp. (Spadi et al., 2016). These could possibly be correlated with the ostracod fauna of the Fosso Bianco Formation of the Tiberino Basin (Upper PiacenzianGelasian; Basilici, 1995, 1997; Napoleone et al., 2003). Medici and Gliozzi (2008) and Spadi et al. (2017) described the Tiberino Basin as a fossil ancient-lake that gave rise to a Caspiocypris species flock. The San Demetrio synthem and the Fosso Bianco Formation are the only post-Messinian deposits in Italy that are known to bear this genus. This implies a link between the lake deposits of the San Demetrio synthem (L'Aquila Basin) and the Upper PiacenzianGelasian lacustrine succession of the Fosso Bianco Formation (Tiberino Basin), indicating a late Piacenzian age for the onset of deposition in both intermontane basins.

Based on this correlation, the first phase of basin filling in the L'Aquila Basin occurred during the late Piacenzian-Gelasian interval. In the eastern part of the basin (Paganica-San NicandroCastelnuovo subbasin, San Demetrio synthem; Spadi et al., 2016), lake deposits give way to transitional deposits toward the former lake margins, and finally to carbonate talus breccias associated with the basin margin (Bertini and Bosi, 1993). At the same time, in the western part of the basin (L'Aquila-Scoppito subbasin), slope-derived breccias, debris-flow deposits, and alluvial clayey-sandy conglomerates of the Colle CantaroCave synthem characterize the first phase of basin fill. Based on the Pettino 1 seismic reflection profile (Fig. 5), this latter synthem is represented by the wedge-shaped seismic facies R, which was deposited during the synrift stage of the L'AquilaScoppito subbasin, and it defines the onset of extension responsible for the development of the L'Aquila intermontane basin.

\section{Postrift Evolution of L'Aquila Basin and Surrounding Regions: The Gelasian- Calabrian Transition}

In L'Aquila Basin, the Madonna della Strada synthem (Calabrian) is cut into the abandon- ment surface of the San Demetrio synthem (Valle Daria, $850 \mathrm{~m}$ above sea level), which regionally corresponds to the Gelasian abandonment surface of the Rieti basin fill (Barisone et al., 2014; Cosentino et al., 2014; Fubelli et al., 2014; Fig. DR1 [see footnote 1]). Similarly, in the Tiberino Basin, above the Upper Piacenzian-Gelasian lake sediments, a prominent angular unconformity separates the Fosso Bianco Formation from the overlying Lower Pleistocene deposits of braided stream and marshy alluvial plain origin (Santa Maria di Ciciliano Formation; Basilici, 1995, 1997). This younger unit bears large mammal faunas referable to the Olivola, Tasso, and Farneta FUs (Uppermost Gelasian-Calabrian pro parte; Sardella et al., 2003). Thus, the Santa Maria di Ciciliano deposits (Tiberino Basin) are correlatable with the Calabrian deposits of the Madonna della Strada synthem (L'Aquila Basin). The Gelasian abandonment surfaces of both the L'Aquila and Rieti intermontane basins (Fig. DR1 [see footnote 1]), as well as the angular unconformity between the Fosso Bianco and the Santa Maria di Ciciliano formations (Fig. 13), were probably triggered by a $260 \mathrm{~m}$ relative sea-level drop (tectonic uplift + glacio-eustasy) that occurred close to the Gelasian-Calabrian transition at the Tyrrhenian margin of the central Apennines, as indicated in the Pliocene-Quaternary succession of the Rome area (Cosentino and Fubelli, 2008; Cosentino et al., 2009).

In the L'Aquila-Scoppito subbasin, the angular unconformity separating the Colle CantaroCave and the Madonna della Strada synthems defines the boundary between the synrift and postrift stages of the basin. The early postrift stage of L'Aquila Basin filling, which occurred during the Calabrian, was mainly characterized by the deposition of fine-grained deposits of the Madonna della Strada synthem. The Pettino 1 profile shows variable thicknesses of the seismic units that can be referred to the Madonna della Strada synthem, implying a highly irregular top of the bedrock during the postrift stage of the L'Aquila-Scoppito subbasin. A deep Calabrian depocenter in the western L'Aquila Basin, imaged in the Pettino 1 seismic profile (Fig. 5), indicates that the Madonna della Strada synthem reached thicknesses up to $200 \mathrm{~m}$ close to the Mount Pettino active fault.

Based on the ostracod and mollusc assemblages from the BAR 20 section, combined with the lithostratigraphy of the Lower Pleistocene deposits of L'Aquila-Scoppito subbasin, including at least five horizons of lignite, the finegrained deposits of the Madonna della Strada synthem can be interpreted as deposits of floodplains with extensive swamps located close to meandering fluvial channels.
Although the Madonna della Strada synthem has been referred by all previous authors to the early Pleistocene (Calabrian), its precise age is a matter of debate. According to Magri et al. (2010), the rich fauna of large mammals (including a complete skeleton of Mammuthus meridionalis; Maccagno, 1958, 1962, 1965; Magri et al., 2010; Mancini et al., 2012) and small vertebrates (Kotsakis, 1988; Esu et al., 1992) discovered at the Santarelli quarry points to the latest Villafranchian Farneta or Pirro FU (ca. 1.6-1.2 Ma; Gliozzi et al., 1997). In contrast to this interpretation, Mancini et al. (2012) referred the faunas of the Santarelli quarry to both the Pirro and Colle Curti FU (latest Villafranchian to Epivillafranchian Mammal Ages; ca. 1.4-0.9 Ma). More recently, new findings from the upper part of the Madonna della Strada synthem (BAR 20 section, Campo di Pile), which include a nonadvanced form of Mammuthus meridionalis and scanty material referable to Equus sp. and a large-sized cervid, were considered by Agostini et al. (2012) to possibly pertain to the Colle Curti FU (Epivillafranchian Mammal Age). This conclusion leads to extension of the age of the Madonna della Strada synthem up to the uppermost part of the Lower Pleistocene (ca. 1.1-0.9 Ma).

In contrast, the large mammal assemblage within the BAR 20 section, together with those reported in Agostini et al. (2012) from the same locality, suggests an age equivalent to the Pirro FU (ca. 1.4-1.2 Ma), or slightly younger, but definitely older than the Colle Curti FU (ca. 1.1-0.9 Ma). Both early Pleistocene large mammal sites from the L'Aquila-Scoppito subbasin (Santarelli quarry and the BAR 20 section) are from the uppermost part of the Madonna della Strada synthem, close to the boundary with the Middle Pleistocene Fosso di Genzano synthem. Thus, the discussed age constraints from the large mammals should be applied only to the uppermost part of the Madonna della Strada synthem.

From a paleoclimate perspective, the palynological analyses carried out on samples from the Santarelli quarry suggest the occurrence of a forest phase corresponding to a warm interglacial period (MIS 37 or 35; Magri et al., 2010). However, the occurrence of Eucypris dulcifrons in the ostracod assemblage from the BAR 20 section, which is typical of the cold climate assemblages of Pleistocene glacial intervals (Fuhrmann et al., 1997; Fuhrmann, 2012), points to the occurrence of a cool or cold climate phase. Both results are consistent with early Pleistocene glacialinterglacial climate changes in the intermontane L'Aquila Basin, possibly forced by the cyclical variation of Earth's orbital obliquity (e.g., 41 k.y. cycle; Milankovitch, 1941). 


\section{Youngest Tectono-Stratigraphic Relationships in the Postrift Phase of L'Aquila Basin Filling}

After the two major phases of basin filling (late Piacenzian-Gelasian and Calabrian), the L'Aquila intermontane basin was affected by five shorter tectono-sedimentary events. Those events gave rise to deposition of Middle and Upper Pleistocene unconformity-bounded stratigraphic units. Tectonically driven variations of the local base level and/or climate changes were responsible for the Middle to Upper Pleistocene stratigraphic evolution of the L'Aquila Basin.

The lower Middle Pleistocene Colle di Genzano synthem is mainly related to the distal portions of alluvial fans, laterally passing to alluvial plains. The Colle di Genzano synthem is well constrained by the appearance of mammalian taxa typical of the Italian Epivillafranchian to Galerian faunas, earlier than the Isernia La Pineta FU (ca. 0.6 Ma; Palombo et al., 2010), as well as by the occurrence of ash layers with a ${ }^{39} \mathrm{Ar} /{ }^{40} \mathrm{Ar}$ age of $520 \pm 5 \mathrm{ka}$ (Gaeta et al., 2010).

In this paper, the Colle Macchione-L'Aquila synthem, which is mainly characterized by carbonate breccia and megabreccia deposits supplied by sturzstroms (sensu Hsü, 1975; Pierson and Costa, 1987) from the northern margin of the L'Aquila Basin, is considered to have been deposited during an arid climate phase possibly linked to a late middle Pleistocene glacial event. Considering the relative stratigraphic position of this synthem with respect to the Upper Pleistocene deposits of the L'Aquila-Scoppito subbasin, this glacial event could correlate with MIS 6 or MIS 8.

The Upper Pleistocene Fosso Vetoio, Campo di Pile, and Ponte Peschio synthems reflect the late Quaternary evolution of the L'Aquila Basin, which at that time was mainly characterized by confined fluvial systems in narrow alluvial braided plains with channelized gravel deposits related to the Raio Stream and the Aterno River (Fig. 12). Carbonized plant remains recovered in the sandy layers of the Campo di Pile synthem allow this strath terrace to be constrained to a ${ }^{14} \mathrm{C} 2 \sigma$ age of $41,854-40,464$ cal yr B.P. (MIS 3). Since that time, the fluvial system in the L'Aquila-Scoppito subbasin has incised at a rate between 0.24 and $0.32 \mathrm{~mm} / \mathrm{yr}$, which is consistent with the middle to late Pleistocene incision rates estimated from cosmogenic nuclide data for the central-northern Apennines by Cyr and Granger (2008). In contrast, higher incision rates were estimated by Wegmann and Pazzaglia (2009) for the northern Apennines using ${ }^{14} \mathrm{C}$ deposit ages. These authors estimated incision rate of $1.6 \mathrm{~mm} / \mathrm{yr}$ for a $30 \pm 5 \mathrm{ka}$ strath terrace along the Bidente River valley (Ro- magna, northern Apennines), whereas along the Musone River (Marche, northern Apennines), strath terraces show that bedrock incision proceeded at $0.6 \mathrm{~mm} / \mathrm{yr}$ over the last $40 \pm 5 \mathrm{k} . \mathrm{y}$. The differences in the incision rates for adjacent northern Apennine basins could be related to differences in lithology, river incision processes, and/or local tectonics. However, from the intermontane Tiberino Basin (central Apennines), a calcareous tufa sample from a fluvial terrace $(82 \pm 7 \mathrm{ka})$ provided an incision rate of $0.3-0.35 \mathrm{~mm} / \mathrm{yr}$ (Pucci et al., 2014), which is comparable to the incision rate of the L'Aquila Basin over the past $40 \mathrm{k} . \mathrm{y}$. Although fluctuations in river incision rates over intermediate time scales cannot be excluded, the results from the Tiberino Basin imply a relatively steady incision rate during the late Pleistocene for both these intermontane basins of the central Apennines. Following this assumption, ages of 71-89 ka (MIS 5a) and 18-25 ka (MIS 2) are suggested for the Fosso Vetoio and Ponte Peschio synthems, respectively, in L'Aquila Basin.

The geometric relationships between the L'Aquila-Scoppito subbasin fill and the fault planes also show a northeastward migration of the fault deformation toward the present-day Mount Pettino active fault at the northern margin of the L'Aquila-Scoppito subbasin. This is evident in the southern part of the Pettino 1 seismic profile, where some faults are sealed by the seismic facies L (Madonna della Strada synthem, upper Lower Pleistocene). Closer to the Mount Pettino slope, they are sealed by the seismic facies BC (Colle Macchione-L'Aquila synthem, upper Middle Pleistocene) and AD (youngest deposits of the L'Aquila-Scoppito subbasin fill, Upper Pleistocene), and, finally, the Mount Pettino active fault cuts through the AD seismic facies (Fig. 5).

\section{New Insights into the Evolution of the Apennine Postorogenic Extensional Domain}

The late Piacenzian (ca. $3 \mathrm{Ma}$ ) onset of the Tiberino and L'Aquila extensional basins calls into question previous suggestions that the onset of these basins becomes younger from the Tyrrhenian toward the Adriatic side of the central Apennines (Cavinato and DeCelles, 1999; Galadini and Messina, 2004). Indeed, according to the synrift ages of the intermontane basins across the northern and central Apennines, only two major extensional domains can be recognized: (1) a late Miocene rifting event, which includes all the late Miocene extensional basins in Tuscany (Liotta, 1996; Pascucci et al., 1999; Brogi, 2006); and (2) a late Pliocene to earliest Pleistocene rifting event, which, in the central
Apennines, possibly includes all the intermontane basins from the Tiberino Basin to the Sulmona Basin (Fig. 14).

The time gap between shortening and extension that has been used to reconstruct both a seismotectonic model for central Italy (Lavecchia et al., 1994) and a model to estimate the rate of rock uplift in the contractional part of the Apennines (Cavinato and DeCelles, 1999) is questioned. These models assume that the central Apennine extensional deformation migrated eastward $\sim 2$ m.y. after the Apennine compressional front. Although this temporal evolution of deformation could be true for L'Aquila Basin, for the Tiberino Basin, which records late Serravallian (ca. $12 \mathrm{Ma}$ ) compressional deformation (Belvedere-Vallocchia thrust-top basin; Cipollari and Cosentino, 1997; Fig. 15) and a late Pliocene-early Pleistocene synrift stage (Collettini and Barchi, 2002; Pucci et al., 2014), the time gap between compression and extension is much longer ( 9 m.y.).

The different time gaps between compressional and extensional deformation at any given locality in the central Apennines (Fig. 15) could indicate a partial decoupling of processes responsible for the migration of shortening and extension toward the foreland. These processes include (1) convergence and rollback of the subducting plate, responsible for the migration of the compressional front toward the foreland (e.g., Doglioni et al., 1997; Funiciello et al., 1999; Faccenna et al., 2001; Carminati and Doglioni, 2012), and (2) mantle upwelling, responsible for the development of the hinterland extensional domain, the uplift of the compressional tectonic wedge, and intermontane extensional basin formation (e.g., Dewey, 1988; Doglioni, 1995; Faccenna et al., 1996; Cavinato and DeCelles, 1999; D'Agostino et al., 2001; Fig. 16). Observation of diachroneity between the eastward migration of the shortening in the foreland and extension in the inner part of the orogen supports the notion that the central Apennines were created as a result of a partially decoupled collision zone. It could be due to the occurrence of large hydrated and partially molten low-viscosity areas in the mantle wedge above the subducting slab of the Adria plate. A similar geodynamic setting has recently been suggested for the northern Apennines of Italy (Faccenda et al., 2009) to explain the thin crustal wedge and the bimodal distribution of stresses within the orogen, with compressional stress in the foreland and extensional stress in the inner part of the northern Apennines. A similar tectonic scenario characterizes the western Pacific subduction zones, which show seismic decoupling and back-arc spreading, such as Mariana, Kermadec, South Tonga, South Ryukyu, etc. 


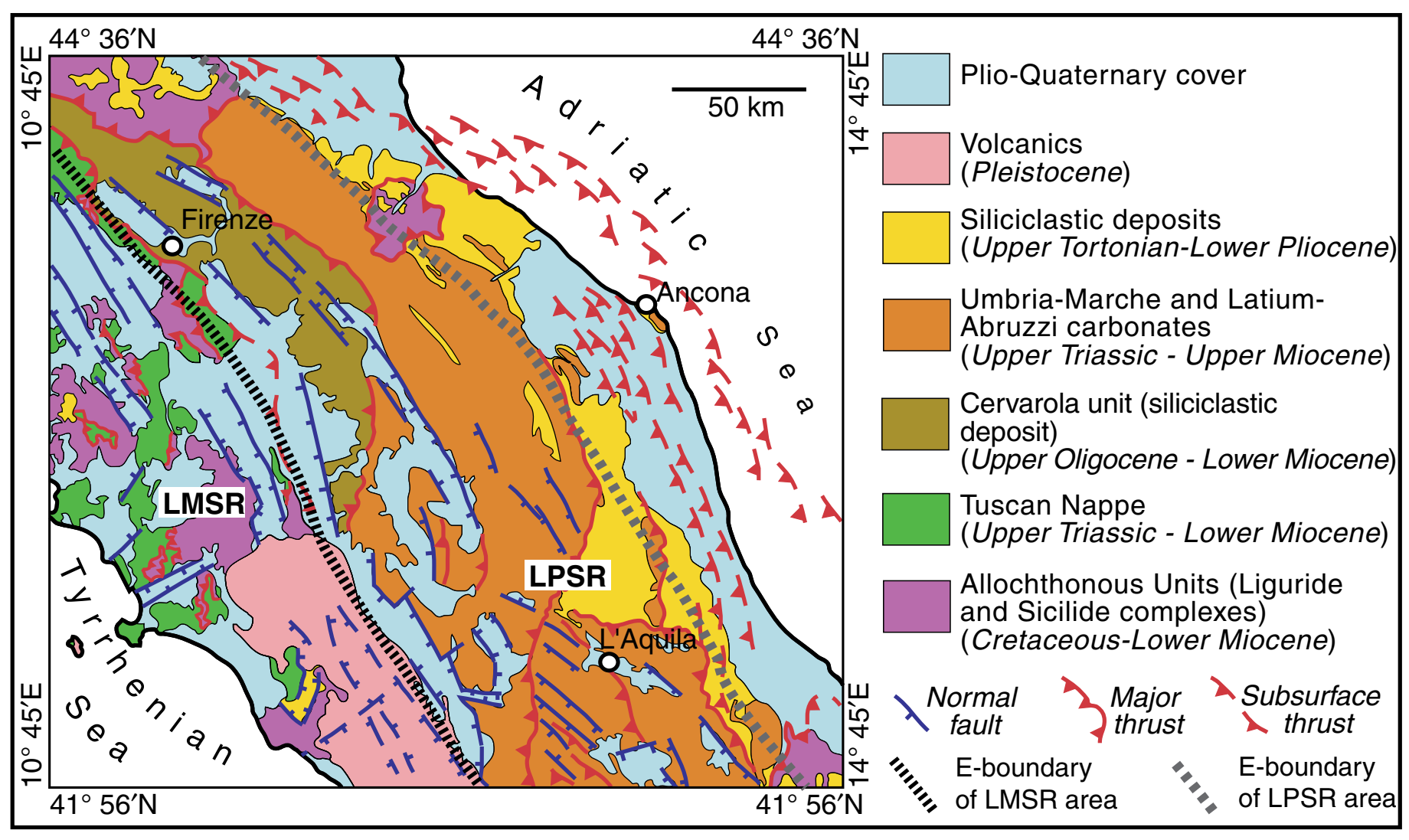

Figure 14. Geological map of central-northern Italy with extension of the postorogenic synrift domains. LMSR-late Miocene synrift area (data from Liotta, 1996; Pascucci et al., 1999; Brogi, 2006); LPSR-late Pliocene to earliest Pleistocene synrift area (data from Collettini and Barchi, 2002; Pucci et al., 2014; this work).

(e.g., Kanamori, 1977; Uyeda and Kanamori, 1979; Scholz and Campos, 1995), as well as the eastern Mediterranean subduction zone of the Aegean system (Bohnhoff et al., 2001; Burov et al., 2001; Faccenna et al., 2003; van Hinsbergen et al., 2005).

As indicated by the high seismicity that characterizes the youngest fault planes in the central Apennine intermontane basins (Collettini and Barchi, 2002; Falcucci et al., 2011; Tallini et al., 2012; Storti et al., 2013; Gori et al., 2014; Pucci et al., 2014), the extensional deformation responsible for the creation of these basins is still active over the whole domain that was affected by the late Plioceneearly Pleistocene synrift extension (from the Tiberino Basin in the west to the Sulmona Basin in the east). In this scenario, the intermontane basins of the central Apennines record $\sim 3$ m.y. of continued crustal extension in response to a first phase of mantle upwelling above the Adria subducting slab (from 3 to $2 \mathrm{Ma}$; Fig. 16) and a second phase of dynamic mantle upwelling possibly starting from ca. $2 \mathrm{Ma}$, probably due to slab detachment under the central Apennines (Faccenna et al.,
2014). The second phase of mantle upwelling could be responsible for the strong tectonic uplift $(\sim 260 \mathrm{~m})$ that occurred in central Italy close to the Gelasian-Calabrian transition (Cosentino et al., 2009), which possibly induced the early Pleistocene reorganization of the central Apennine drainage systems (Fubelli et al., 2014; Piacentini and Miccadei, 2014).

\section{CONCLUSIONS}

The extensional intermontane basins of central Italy are a good example of tectonically controlled sedimentary basins developed in the postorogenic phase of a mature orogen. Their fill reveals the timing and modalities of postorogenic extensional tectonics that have been affecting the Apennines of Italy since the late Pliocene. New insights into the tectonostratigraphic evolution of L'Aquila Basin and comparison with the evolution of the Tiberino Basin allow the major regional events of their geological history to be identified. Ostracod assemblages from these basins indicate that the lake deposits of the San Demetrio synthem (Limi di San Nicandro Auctorum, L'Aquila
Basin, Paganica-San Nicandro-Castelnuovo subbasin) correlate with the Upper PiacenzianGelasian Fosso Bianco Formation (Tiberino Basin). In the western part of the L'Aquila Basin (L'Aquila-Scoppito subbasin), deposits belonging to this first phase of basin filling form the Colle Cantaro-Cave synthem (Upper Piacenzian-Gelasian). The Pettino 1 seismic reflection profile, which is close to the northern margin of the L'Aquila-Scoppito subbasin (southern Mount Pettino slope), shows wedge-shaped seismic facies characterizing the older basin fill of the western L'Aquila Basin (i.e., the Colle Cantaro-Cave synthem). These observations are consistent with a late Piacenzian-Gelasian synrift stage being responsible for the development of the L'Aquila extensional intermontane basin. The same age is indicated for the onset of the Tiberino and L'Aquila Basins, which calls into question previous suggestions that the extensional intermontane basins become younger moving from the Tyrrhenian side toward the Adriatic side of the central Apennines.

No lake environments developed in the L'Aquila Basin after the Gelasian-Calabrian unconformity (Madonna della Strada synthem). 


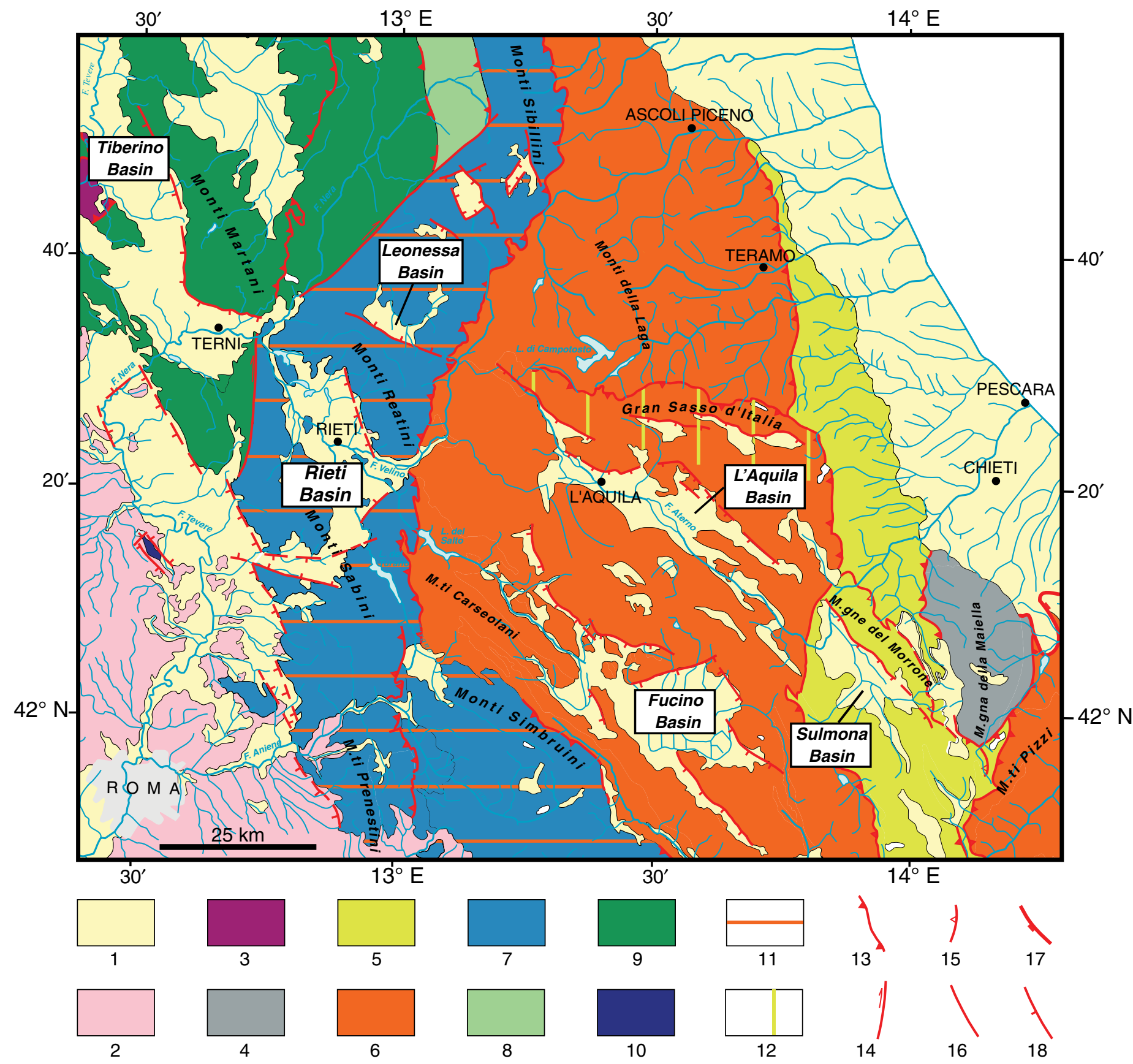

Figure 15. Kinematic map of the study area showing the difference in time lag between the orogenic shortening and the earliest extension responsible at ca. $3 \mathrm{Ma}$ for the onset of the postorogenic intermontane basins. 1-Pliocene-Quaternary continental and marine deposits; 2-middle Pleistocene volcanic rocks; 3-allochthonous Apennine units piled up during the earliest Apennine orogenic events and successively transported onto more external domains until Pliocene time; 4-Apennine units affected by orogenic transport during late Pliocene; 5-Apennine units affected by orogenic transport during late early Pliocene; 6-Apennine units affected by orogenic transport during latest Messinian-early Pliocene; 7-Apennine units affected by orogenic transport during early Messinian; 8-Apennine units affected by orogenic transport during late Tortonian; 9-Apennine units affected by orogenic transport during late Serravallian; 10Apennine units affected by orogenic transport during late Burdigalian; 11-Apennine units reactivated during the latest Messinian-early Pliocene tectonic event; 12-Apennine units reactivated during the late early Pliocene tectonic event; 13—major thrust mainly bounding regional kinematic units; 14-strike-slip fault; 15-minor thrust within the same kinematic unit; 16-undifferentiated fault; 17—front of the allochthonous Apennine units; 18-main extensional fault. 


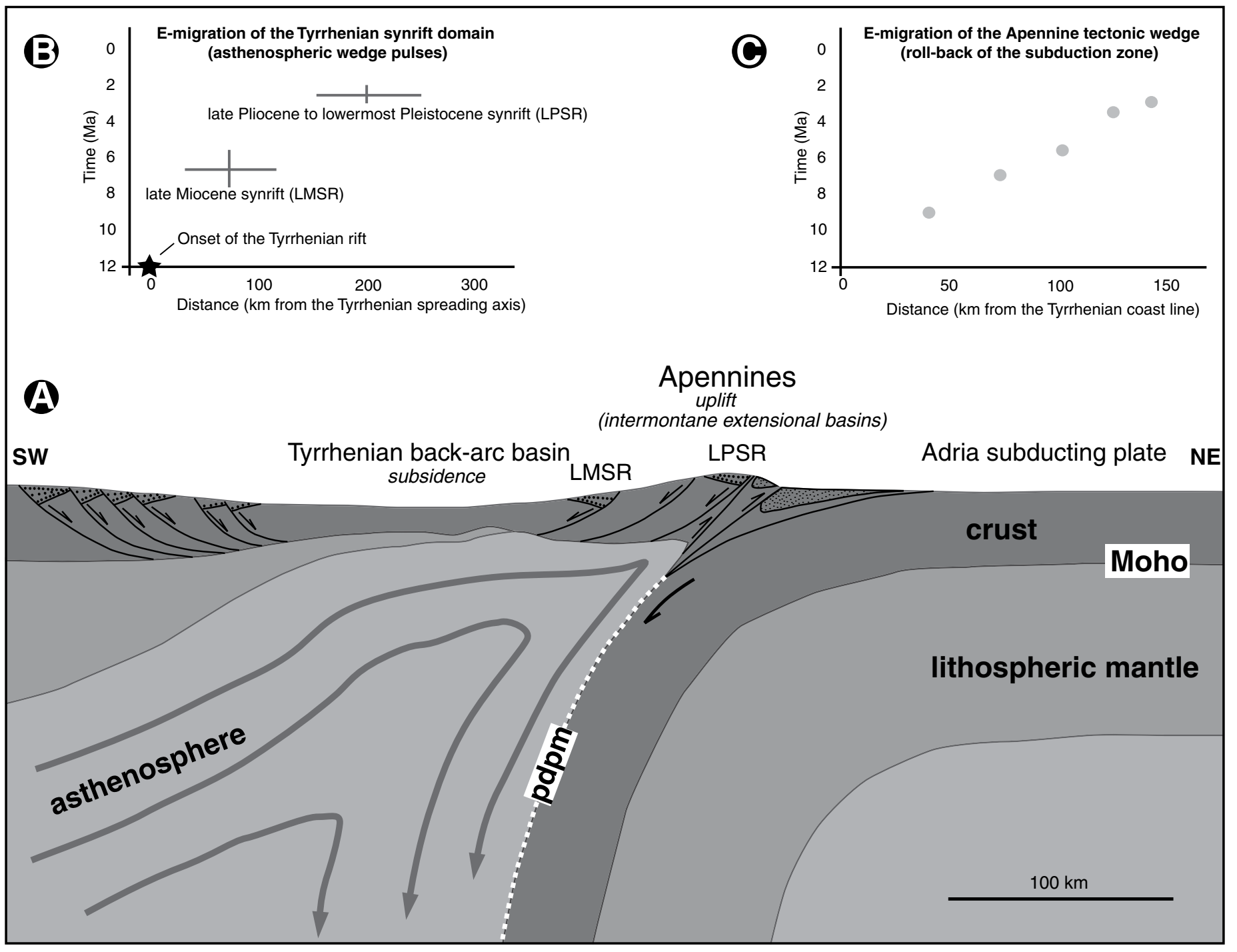

Figure 16. (A) Geological cross section of the eastward-migrating Apennine subducting system. The episodes of tectonic activity of both (B) the Tyrrhenian synrift domain and (C) the Apennine tectonic wedge, migrating toward the foreland, are also shown. During the Tortonian-Pliocene migration of the Apennine orogenic system, four episodes of Apennine tectonic wedge formation (C; data from Patacca et al., 1992; Cosentino et al., 2010) correspond to only two Tyrrhenian synrift stages (B; data from Liotta, 1996; Pascucci et al., 1999; Collettini and Barchi, 2002; Brogi, 2006; Pucci et al., 2014; this work), possibly evidencing a partial decoupling between the roll-back of the subduction zone and the episodes of mantle upwelling in the Tyrrhenian area. LMSR-late Miocene synrift area (data from Liotta, 1996; Pascucci et al., 1999; Brogi, 2006); LPSR-late Pliocene to earliest Pleistocene synrift area (data from Collettini and Barchi, 2002; Pucci et al., 2014; this work); pdpm-partially decoupled plate margin.

During the Calabrian stage (1.82-0.78 Ma), floodplains with extended swamp areas close to meandering fluvial channels developed. New large mammal findings from the BAR $20 \mathrm{sec}-$ tion, coupled with previously reported mammalian fauna from the Santarelli quarry (Magri et al., 2010) and the BAR 20 section (Campo di Pile; Agostini et al., 2012), indicate an age referable to the Pirro FU, or slightly younger, but definitely older than the Colle Curti FU.

The main active faults of the extensional fault system responsible for the onset of the L'Aquila intermontane basin migrated from southwest to northeast, reaching the present position of the active Mount Pettino normal fault only in late Pleistocene-Holocene times. The late Pleistocene evolution of the western part of the L'Aquila Basin (L'Aquila-Scoppito subbasin) was characterized by the development of at least two strath terraces. The older Campo di Pile synthem correlates with MIS 3 , as it has a ${ }^{14} \mathrm{C}$ $2 \sigma$ age of $41,854-40,464$ cal yr B.P. From this age, late Quaternary river incision rates between 0.24 and $0.32 \mathrm{~mm} / \mathrm{yr}$ can be estimated, which are consistent with incision rates suggested for the northern and central Apennines since the middle Pleistocene (Cyr and Granger, 2008; Pucci et al., 2014). In addition, assuming these incision rates to be constant for the L'Aquila Basin from late Pleistocene to present time, then ages of 71-89 ka (MIS 5a) and 18-25 ka (MIS 2) for the Fosso Vetoio synthem and the Ponte Peschio synthem are indicated.

From a plate-tectonics perspective, a partial decoupling of the roll-back of the subducting Adria plate and episodes of mantle upwelling 
beneath the overriding plate (Apennines) could explain the different time gaps between compressional and extensional deformation in the late Neogene-Quaternary tectonic record of the central-northern Apennines. These new insights into the evolution of the central Apennine postorogenic extensional domain, which represents an archive of $\sim 3$ m.y. of continued crustal extension, may be useful in constraining the longterm (Pliocene-Quaternary) extension rates in the central Apennines, as well as providing a more reliable basis for seismotectonic models for one of the most seismically active sectors of the central Mediterranean region.

\section{ACKNOWLEDGMENTS}

We would like to thank Centro di Ricerca e Formazione per l'Ingegneria Sismica (CERFIS), L'Aquila University, for granting access to the seismic reflection profile and all the Istituto per l'Ambiente Marino Costiero del Consiglio Nazionale delle Ricerche (IAMC-CNR) staff who participated in the seismic acquisition and processing. We especially thank the Soprintendenza per i Beni Archeologici dell'Abruzzo, who authorized the study of the fossil vertebrates. This manuscript benefited from helpful reviews by Taylor Schildgen, John Wakabayashi, Darrel G.F. Long, Vincenzo Pascucci, an anonymous reviewer, and GSA Bulletin editors. This work was carried out within the general agreement between L'Aquila University (Dipartimento di Ingegneria Civile, Edile-Architettura, Ambientale) and Roma Tre University (Dipartimento di Scienze).

\section{REFERENCES CITED}

Abbazzi L., 2004, Remarks on the validity of the generic name Praemegaceros Portis 1920, and an overview on Praemegaceros species in Italy: Rendiconti Fisici dell'Accademia dei Lincei, ser. 9, v. 15, p. 115-132.

Agostini, S., Palombo, M.R., Rossi, M.A., Di Canzio, E., and Tallini, M., 2012, Mammuthus meridionalis (Nesti, 1825) from Campo di Pile (L'Aquila, Abruzzo, central Italy): Quaternary International, v. 276-277, p. 42-52, doi:10.1016/j.quaint.2012.05.013.

Alberdi, M.T., and Palombo, M.R., 2013, The late early to early middle Pleistocene stenonoid horses from Italy: Quaternary International, v. 288, p. 25-44, doi:10.1016/j.quaint.2011.12.005

Amato, A., Chiarabba, C., and Selvaggi, G., 1997, Crustal and deep seismicity in Italy (30 years after): Annali di Geofisica, v. 40, p. 981-993.

Amoroso, S., Del Monaco, F., Di Eusebio, F., Monaco, P., Taddei, B., Tallini, M., Totani, F., and Totani, G., 2010, Campagna di Indagini Geologiche, Geotecniche e Geofisiche per lo Studio della Risposta Sismica Locale della Città dell'Aquila: La Stratigrafia dei Sondaggi (Giugno-Agosto 2010): Centro di Ricerca e Formazione per l'Ingegneria Sismica (CERFIS) Report 1, http://www.cerfis.it/en/download/cat_view/67 -pubblicazionicerfis/68-reports (accessed April 2017).

Bagh, S., Chiaraluce, L., De Gori, P., Moretti, M., Govoni, A., Chiarabba, C., Di Bartolomeo, P., and Romanelli, M., 2007, Background seismicity in the Central Apennines of Italy: The Abruzzo region case study: Tectonophysics, v. 444 , p. $80-92$, doi:10.1016/j.tecto .2007.08.009.

Barisone, G., Esu, D., Gliozzi, E., Kotsakis, T., and Pontini, M.R., 2014, Inquadramento biocronologico e paleo ambientale dei depositi plio-pleistocenici, in Cosentino, D., et al., eds., Note Illustrative della Carta Geologica d'Italia alla scala 1:50,000, Foglio 357Cittaducale: Rome, Italy, Istituto Superiore per la
Protezione e la Ricerca Ambientale (ISPRA)-Servizio Geologico d'Italia, Ente Realizzatore Università degli Studi Roma Tre, p. 143, http://www.isprambiente.gov .it/Media/carg/note_illustrative/357_Cittaducale.pdf (accessed April 2017).

Basilici, G., 1995, Sedimentologia della parte distale di una conoide alluvionale del Pliocene superiore (Bacino Tiberino, Umbria): Il Quaternario, v. 8, p. 37-52.

Basilici, G., 1997, Sedimentary facies in an extensional and deep-lacustrine depositional system: The Pliocene Tiberino Basin, central Italy: Sedimentary Geology, v. 109,p. 73-94, doi:10.1016/S0037-0738(96)00056-5.

Bellucci, L., Sardella, R., and Rook, L., 2015, Large mammal biochronology framework in Europe at Jaramillo-The Epivillafranchian as a formal biochron: Quaternary International, v. 389, p. 84-89, doi:10.1016/j.quaint.2014.11.012.

Bertini, T., and Bosi, C., 1976, Sedimenti continentali probabilmente pliocenici nella Valle del Salto e nella Conca del Fucino (Rieti e L'Aquila): Bollettino della Società Geologica Italiana, v. 95, p. 767-801.

Bertini, T., and Bosi, C., 1993, La tettonica quaternaria della conca di Fossa (L'Aquila): Il Quaternario, v. 6, p. 293-314.

Bohnhoff, M., Makris, J., Papanikolaou, D., and Stavrakakis, G., 2001, Crustal investigation of the Hellenic subduction zone using wide aperture seismic data: Tectonophysics, v. 343, p. 239-262, doi:10.1016/ S0040-1951(01)00264-5.

Bosi, C., 1989, Tentativo di correlazione fra le successioni Plio-Pleistoceniche, in Elementi di Tettonica Pliocenico-Quaternaria ed Indizi di Sismicità Olocenica nell'Appennino Laziale-Abruzzese: Rome, Italy, Società Geologica Italiana, p. 97-104.

Bosi, C., and Messina, P., 1991, Ipotesi di correlazione fra successioni morfo-litostratigrafiche plio-pleistoceniche nell'Appennino Laziale-Abruzzese: Studi Geologici Camerti Special Volume 1991-2, p. 257-263.

Bosi, C., Galadini, F., Giaccio, B., Messina, P., and Sposato, A., 2003, Plio-Quaternary continental deposits in the Latium-Abruzzi Apennines: The correlation of geological events across different intermontane basins: Il Quaternario, v. 16, p. 55-76.

Brogi, A., 2006, Neogene extension in the Northern Apennines (Italy): Insights from the southern part of the Mt. Amiata geothermal area: Geodinamica Acta, v. 19, p. 33-50, doi:10.3166/ga.19.33-50.

Burov, E., Jolivet, L., Le Pourhiet, L., and Poliakov, A., 2001, A thermomechanical model of exhumation of high pressure (HP) and ultra-high pressure (UHP) metamorphic rocks in Alpine-type collision belts: Tectonophysics, v. 342, p. 113-136, doi:10.1016/ S0040-1951(01)00158-5

Carminati, E., and Doglioni, C., 2012, Alps vs. Apennines: The paradigm of a tectonically asymmetric Earth: Earth-Science Reviews, v. 112, p. 67-96, doi:10.1016/j.earscirev.2012.02.004.

Cavinato, G.P., 1993, Recent tectonic evolution of the Quaternary deposits of the Rieti Basin (Central Apennines, Italy): Southern part: Geologica Romana, v. 29, p. $411-434$

Cavinato, G.P., and DeCelles, P.G., 1999, Extensional basins in the tectonically bimodal Central Apennines fold-thrust belt, Italy: Response to corner flow above a subducting slab in retrogrademotion: Geology, v.27,p.955-958, doi:10.1130/ 0091-7613(1999)027<0955:EBITTB>2.3.CO;2.

Cavinato, G.P., Carusi, C., Dall'Asta, M., Miccadei, E., and Piacentini, T., 2002, Sedimentary and tectonic evolution of Plio-Pleistocene alluvial and lacustrine deposits of Fucino Basin (central Italy): Sedimentary Geology, v. 148, p. 29-59, doi:10.1016/S0037-0738(01)00209-3.

Centamore, E., and Dramis, F., 2010, Note Illustrative della Carta Geologica d'Italia alla scala 1:50,000, Foglio 358-Pescorocchiano: Istituto Superiore per la Protezione e la Ricerca Ambientale (ISPRA)-Servizio Geologico d'Italia, Ente Realizzatore Regione Lazio, Rome, Italy, 147 p., http://www.isprambiente.gov.it/ Media/carg/note_illustrative/358_Pescorocchiano.pdf (accessed April 2017)

Centamore, E., and Rossi, D., 2009, Neogene-Quaternary tectonics and sedimentation in the Central Apennines: Italian Journal of Geosciences, v. 128, p. 73-88.
Centamore, E., Crescenti, U., and Dramis, F., 2006, Note Illustrative della Carta Geologica d'Italia alla scala 1:50,000, Foglio 359-L'Aquila: Agenzia per la protezione dell'ambiente e per i servizi tecnici (APAT)-Dipartimento Difesa del Suolo-Servizio Geologico d'Italia, Ente Realizzatore Regione Abruzzo, Rome, Italy, 128 p., http://www.isprambiente.gov.it/ Media/carg/note_illustrative/359_LAquila.pdf (accessed April 2017).

Cipollari, P., and Cosentino, D., 1995, Miocene unconformities in Central Apennines: Geodynamic significance and sedimentary basin evolution: Tectonophysics, v. 252, p. 375-389, doi:10.1016/0040-1951(95)00088-7.

Cipollari, P., and Cosentino, D., 1996, Miocene tectonosedimentary events and geodynamic evolution of the Central Apennines (Italy): Notes et Mémoires du Service Géologique du Maroc, v. 387, p. 163-176.

Cipollari, P., and Cosentino, D., 1997, Il bacino di Belvedere-Vallocchia (Monti di Spoleto): Un thrusttop basin dell'Appennino serravalliano: Bollettino della Società Geologica Italiana, v. 116, p. 347-362.

Cipollari, P., Cosentino, D., Esu, D., Girotti, O., Gliozzi, E., and Praturlon, A., 1999a, Thrust-top lacustrinelagoonal basin development in accretionary wedges: Late Messinian (Lago-Mare) episode in the Central Apennines (Italy): Palaeogeography, Palaeoclimatology, Palaeoecology, v. 151, p. 149-166, doi:10.1016/ S0031-0182(99)00026-7.

Cipollari, P., Cosentino, D., and Gliozzi, E., 1999b, Extension- and compression-related basins in central Italy during the Messinian Lago-Mare event: Tectonophysics, v. 315 , p. 163-185, doi:10.1016/ S0040-1951(99)00287-5.

Collettini, C., and Barchi, M.R., 2002, A low-angle normal fault in the Umbria region (central Italy): A mechanical model for the related microseismicity: Tectonophysics, v. 359, p. 97-115, doi:10.1016/ S0040-1951(02)00441-9.

Cosentino, D., and Fubelli, G., 2008, Comment on: "Geomorphological, paleontological and ${ }^{87} \mathrm{Sr} /{ }^{86} \mathrm{Sr}$ isotope analyses of early Pleistocene paleoshorelines to define the uplift of Central Apennines (Italy)": Quaternary Research, v. 69, p. 163-164, doi:10.1016/j .yqres.2007.07.014

Cosentino, D., Cipollari, P., Di Bella, L., Esposito, A., Faranda, C., Giordano, G., Gliozzi, E., Mattei, M., Mazzini, I., Porreca, M., and Funiciello, R., 2009, Tectonics, sea-level changes and palaeoenvironments in the early Pleistocene of Rome (Italy): Quaternary Research, v. 72 , p. 143-155, doi:10.1016/j .yqres.2009.03.003.

Cosentino, D., Cipollari, P., Marsili, P., and Scrocca, D., 2010, Geology of the Central Apennines: A regional review, in Beltrando, M., Peccerillo, A., Mattei, M. Conticelli, S., and Doglioni, C., eds., The Geology of Italy: Journal of the Virtual Explorer (Electronic Edition), v. 36, paper 11.

Cosentino, D., Miccadei, E., Barberi, R., Basilici, G., Cipollari, P., Parotto, M., and Piacentini, T., 2014, Note Illustrative della Carta Geologica d'Italia alla scala 1:50,000, Foglio 357-Cittaducale: Rome, Italy, Istituto Superiore per la Protezione e la Ricerca Ambientale (ISPRA)-Servizio Geologico d'Italia, Ente Realizzatore Università degli Studi Roma Tre, 143 p.,_http://www.isprambiente.gov.it/ Media/carg/note_illustrative/357_Cittaducale.pdf (accessed April 2017).

Croitor, R., 2006, Taxonomy and systematics of large-sized deer of the genus Praemegaceros Portis, 1920 (Cervidae, Mammalia): Courier Forschungsinstitut Senckenberg, v. 256, p. 91-116

Croitor, R., 2009, Systematical position and evolution of the genus Arvernoceros (Cervidae, Mammalia) from PlioPleistocene of Eurasia: Oltenia, v. 25, p. 375-382.

Cyr, A.J., and Granger, D.E., 2008, Dynamic equilibrium among erosion, river incision, and coastal uplift in the Northern and Central Apennines, Italy: Geology, v. 36, p. 103-106, doi:10.1130/G24003A.1

D'Agostino, N., Jackson, J.A., Dramis, F., and Funiciello, R., 2001, Interactions between mantle upwelling, drainage evolution and active normal faulting: An example from the Central Apennines (Italy): 
Geophysical Journal International, v. 147, p. 475-497, doi:10.1046/j.1365-246X.2001.00539.x.

DeCelles, P.G., and Giles, K.A., 1996, Foreland basin systems: Basin Research, v. 8, p. 105-123, doi:10.1046/j.1365-2117.1996.01491.x.

Demangeot, J., 1965, Géomorphologie des Abruzzes Adriatiques: Lettres [These]: Paris, Éditions du CNRS, $84 \mathrm{p}$

Dewey, J.F., 1988, Extensional collapse of orogens: Tectonics, v. 7, p. 1123-1139, doi:10.1029/ TC007i006p01123.

Diebel, K., and Pietrzeniuk, E., 1969, Ostracoden aus dem Mittelpleistozän von Süssenborn bei Weimar: Paläontologische Abhandlungen, ser. A, v. 3, no. 3-4, p. 463-488.

Doglioni, C., 1995, Geological remarks on the relationships between extension and convergent geodynamic setting: Tectonophysics, v. 252 , p. 253-267, doi:10.1016/0040-1951(95)00087-9.

Doglioni, C., Gueguen, E., Sabat, F., and Fernandez, M., 1997, The Western Mediterranean extensional basins and the Alpine orogen: Terra Nova, v. 9, p. 109-112, doi:10.1046/j.1365-3121.1997.d01-18.x.

Elter, P., Grasso, M., Parotto, M., and Vezzani, L., 2003, Structural setting of the Alpine-Maghrebian thrust belt: Episodes, v. 26, p. 205-211

Esu, D., Girotti, O., and Kotsakis, T., 1992, Molluschi e vertebrati di alcuni bacini continentali dell'Appennino centrale: Indicazioni biostratigrafiche e paleoecologiche: Studi Geologici Camerti Special Volume 1992-2 CROP11, p. 295-299.

Faccenda, M., Minelli, G., and Gerya, T.V., 2009, Coupled and decoupled regimes of continental collision: Numerical modeling: Earth and Planetary Science Letters, v. 278, p. 337-349, doi:10.1016/j .eps1.2008.12.021.

Faccenna, C., Davy, P., Brun, J.-P., Funiciello, R., Giardini, D., Mattei, M., and Nalpas, T., 1996, The dynamics of back-arc extension: An experimental approach to the opening of the Tyrrhenian Sea: Geophysical Journa International, v. 126, p. 781-795, doi:10.1111/j.1365 -246X.1996.tb04702.x.

Faccenna, C., Becker, T.W., Lucente, F.P., Jolivet, L., and Rossetti, F., 2001, History of subduction and backarc extension in the central Mediterranean: Geophysical Journal International, v. 145, p. 809-820, doi:10.1046/j.0956-540x.2001.01435.x.

Faccenna, C., Jolivet, L., Piromallo, C., and Morelli, A., 2003, Subduction and the depth of convection of the Mediterranean mantle: Journal of Geophysical Research, v. 108, no. B2, p. 2099, doi:10.1029/2001JB001690.

Faccenna, C., Becker, T.W., Miller, M.S., Serpelloni, E., and Willet, S.D., 2014, Isostasy, dynamic topography, and the elevation of the Apennines of Italy: Earth and Planetary Science Letters, v. 407, p. 163-174, doi:10.1016/j.epsl.2014.09.027.

Falcucci, E., Gori, S., Moro, M., Pisani, A.M., Melini, D., Galadini, F., and Fredi, P., 2011, The 2009 L'Aquila earthquake (Italy): What's next in the region? Hints from stress diffusion analysis and normal fault activity: Earth and Planetary Science Letters, v. 305 , p. 350 358, doi:10.1016/j.eps1.2011.03.016.

Fischer, S., 1851, Abhandlung ueber das genus Cypris und dessen in der umgebung von St. Petersburg und von Fall bei Reval vorkommenden Arten: Memoires Presentes a l'Academie Imperiale des Sciences de St. Petersburg, v. 7, p. 127-167.

Fisher, R., 1953, Dispersion on a sphere: Proceedings of the Royal Society of London, ser. A, v. 217, p. 295-305, doi:10.1098/rspa.1953.0064.

Fubelli, G., Della Seta, M., and Amato, G., 2014, Drainage system adjustment in response to the opening of the Rieti intermontane basin (central Italy): Geostatistical reconstruction of the paleo-Farfa River alluvial plain: Rendiconti Lincei-Scienze Fisiche e Naturali, v. 25 , p. 167-176, doi:10.1007/s12210-014-0322-0.

Fuhrmann, R., 2012, Atlas quartärer und rezenter Ostrakoden Mitteldeutschlands: Altenburger Naturwissenschaftliche Forschungen, v. 15, p. 1-320.

Fuhrmann, R., von Schirrmeister, L., and Pietrzeniuk, E., 1997, Ostrakoden und Mollusken aus den weichselspätglazialen Sedimenten des Biesenthaler Beckens (N-Barndenburg, Barnim): Zeitschrift für Geologische Wissenschaften, v. 25, p. 489-511.
Funiciello, F., Faccenna, C., and Giardini, D., 1999, Laboratory experiments of subduction: Geophysical Research Abstracts, v. 1, p. 62.

Gaeta, M., Palladino, D.M., Karner, D.B., and Renne, P.R. 2010, Vulcanoclastiti della Valle del Corno, in Centamore, E., and Dramis, F., eds., Note Illustrative della Carta Geologica d'Italia alla scala 1:50,000, Foglio 358-Pescorocchiano: Istituto Superiore per la Protezione e la Ricerca Ambientale (ISPRA)-Servizio Geologico d'Italia, Ente Realizzatore Regione Lazio, Rome, Italy, p. 80-81, http://www.isprambiente.gov.it/ Media/carg/note_illustrative/358_Pescorocchiano.pdf (accessed April 2017)

Galadini, F., and Messina, P., 2004, Early-middle Pleistocene eastward migration of the Abruzzi Apennine (central Italy) extensional domain: Journal of Geodynamics, v. 37, p. 57-81, doi:10.1016/j.jog.2003.10.002

Geomineraria Nazionale (GEMINA), 1963, Ligniti e Torbe dell'Italia Continentale: Torino, Italy, Industria Libraria Tipografica Editrice (ILTE) Ed. Torino IP, 319 p.

Ghisetti, F., and Vezzani, L., 1986, Carta Geologica del Gruppo del M. Sella-M. Camicia-M. Prena-M. Brancastello (Gran Sasso d'Italia, Abruzzo): Firenze, Italy, Società Elaborazioni Cartografiche (SELCA), scale $1: 25,000$

Ghisetti, F., Vezzani, L., and Follador, U., 1993, Transpressioni destre nelle zone esterne dell'Appennino centrale: Geologica Romana, v. 29, p. 73-95.

Giaccio, B., Messina, P., Sposato, A., Voltaggio, M., Zanchetta, G., Galadini, F., Gori, S., and Santacroce, R., 2009, Tephra layers from Holocene lake sediments of the Sulmona Basin, central Italy: Implications for volcanic activity in Peninsular Italy and tephrostratigraphy in the central Mediterranean area: Quaternary Science Reviews, v. 28, p. $2710-2733$, doi:10.1016/j .quascirev.2009.06.009.

Giaccio, B., Galli, P., Messina, P., Peronace, E., Scardia, G., Sottili, G., Sposato, A., Chiarini, E., Jicha, B., and Silvestri, S., 2012, Fault and basin depocentre migration over the last $2 \mathrm{Ma}$ in the L'Aquila 2009 earthquake region, central Italian Apennines: Quaternary Science Reviews, v. 56, p. 69-88, doi:10.1016/j quascirev.2012.08.016.

Girod, A., Bianchi, I., and Mariani, M., 1980, Guida per il Riconoscimento delle Specie Animali delle Acque Interne Italiane: 7. Gasteropodi 1: Rome, Italy, Consiglio Nazionale delle Ricerche, $86 \mathrm{p}$.

Gliozzi, E., Abbazzi, L., Argenti, P., Azzaroli, A., Caloi, L., Capasso Barbato, L., Di Stefano, G., Esu, D., Ficcarelli, G., Girotti, O., Kotsakis, T., Masini, F., Mazza, P., Mezzabotta, C., Palombo, M.R., Petronio, C., Rook, L., Sala, B., Sardella, R., Zanalda, E., and Torre, D. 1997, Biochronology of selected mammals, molluscs and ostracods from the middle Pliocene to the late Pleistocene in Italy: The state of the art: Rivista Italiana di Paleontologia e Stratigrafia, v. 103, p. 369-388.

Gori, S., Giaccio, B., Galadini, F., Falcucci, E., Messina, P., Sposato, A., and Dramis, F., 2011, Active normal faulting along the Mt. Morrone south-western slopes (Central Apennines, Italy): Geologische Rundschau, v. 100, p. 157-171, doi:10.1007/s00531-009-0505-6.

Gori, S., Falcucci, E., Dramis, F., Galadini, F., Galli, P., Giaccio, B., Messina, P., Pizzi, A., Sposato, A., and Cosentino, D., 2014, Deep-seated gravitational slope deformation, large-scale rock failure, and active normal faulting along Mt. Morrone (Sulmona Basin, central Italy): Geomorphological and paleoseismological analyses: Geomorphology, v. 208, p. 88-101, doi:10.1016/j.geomorph.2013.11.017.

Hartwig, W., 1899, Eine neue Candona aus der Provinz Brandenburg: Candona marchica, und die wahre Candona pubescens (Koch): Sitzungs-Berichte der Gesellschaft Naturforschender Freunde zu Berlin 1899, p. $183-189$.

Hsü, K.J., 1975, Catastrophic debris streams (sturzstroms) generated by rockfalls: Geological Society of America Bulletin, v. 86, p. 129-140, doi:10.1130/ 0016-7606(1975)86<129:CDSSGB>2.0.CO;2.

Kahlke, H.-D., 1997, Die Cerviden-Reste aus dem Unterpleistozän von Untermassfeld, in Kahlke, R.-D., ed. Das Pleistozän von Untermassfeld bei Meiningen (Thüringen): Römisch-Germanisches Zentralmuseum Monographien Teil 1, v. 40, p. 181-275.
Kanamori, H., 1977, Seismic and aseismic slip along subduction zones and their tectonic inplications, in Talwani, M., and Pitman, W.C., III, eds., Island Arcs, Deep Sea Trenches and Back-Arc Basins: Washington, D.C., American Geophysical Union, Maurice Ewing Series I, p. 163-174, doi:10.1029/ME001p0163.

Kaufmann, A., 1900, Neue Ostracoden aus der Schweiz: Zoological Anzeiger, v. 23, p. 131-133.

Kirschvink, J.L., 1980, The least-squares line and plane and the analysis of palaeomagnetic data: Geophysical Journal of the Royal Astronomical Society, v. 62, p. 699-718, doi:10.1111/j.1365-246X.1980.tb02601.x.

Klie, W., 1938, Ostracoden aus unterirdischen Gewässern in Süditalien: Zoologischer Anzeiger, v. 123, p. 148-155

Kotsakis, T., 1988, Biostratigraphy of Plio-Pleistocene Arvicolids (rodents) of Italy: Modern Geology, v. 13, p. 163-175.

Lavecchia, G., Brozzetti, F., Barchi, M., Menichetti, M., and Keller, J.V.A., 1994, Seismotectonic zoning in east-central Italy deduced from an analysis of the Neogene to present deformations and related stress fields: Geological Society of America Bulletin, v. 106, p. 1107-1120, doi:10.1130/ 0016-7606(1994)106<1107:SZIECI>2.3.CO;2.

Linnaeus, C., 1758, Systema Naturae per Regna Tria Naturae, Secundum Classes, Ordines, Genera, Species, Cum Characteribus, Differentiis, Synonymis, Locis Ed. 10 Reformata: Holmiae Laurentii Salvii, Uppsala, Sweden, 824 p., http://www.biodiversitylibrary.org/ item/10277\#page/3/mode/1up (accessed April 2017).

Liotta, D., 1996, Analisi del settore centro-meridionale del bacino pliocenico di Radicofani (Toscana meridionale): Bollettino della Società Geologica Italiana, v. 115 , p. $115-143$.

Lourens, L.J., Hilgen, F.J., Laskar, J., Shackleton, N.J., and Wilson, D., 2004, The Neogene Period, in Gradstein, F.M., Ogg, J.G., and Smith, A.G., eds., Geologic Time Scale 2004: Cambridge University Press, Cambridge, United Kingdom, p. 409-440.

Lucifora, S., Cifelli, F., Mattei, M., Sagnotti, L., Cosentino, D., and Roberts, A.P., 2012, Inconsistent magnetic polarities in magnetite- and greigite-bearing sediments: Understanding complex magnetizations in the late Messinian in the Adana basin (southern Turkey) Geochemistry Geophysics Geosystems, v. 13, Q10002, doi: 10.1029/2012GC004248.

Maccagno, A.M., 1958, Relazione sulla tecnica di scavo, restauro e montaggio dell'elefante fossile rinvenuto presso l'Aquila: Annuario Istruzioni alta Cultura: Aquila, v. 2, p. 1-14

Maccagno, A.M. 1962, L'Elephas meridionalis nesti di Contrada Madonna della Strada, Scoppito (AQ): Atti dell'Accademia di Scienze Fisiche e Matematiche di Napoli, ser. 3, v. 4, p. 38-129.

Maccagno, A.M., 1965, Nuovi ritrovamenti di resti elefantini nel Villafranchiano della Conca aquilana: Bollettino della Società dei Naturalisti in Napoli, v. 74, p. 1-22.

Magri, D., Di Rita, F., and Palombo, M.R., 2010, An early Pleistocene interglacial record from an intermontane basin of central Italy (Scoppito, L'Aquila): Quaternary International, v. 225 , p. 106-113, doi:10.1016/j .quaint.2009.04.005.

Mancini, M., Cavuoto, G., Pandolfi, L., Petronio, C., Salari, L., and Sardella, R., 2012, Coupling basin infill history and mammal biochronology in a Pleistocene intramontane basin: The case of western L'Aquila Basin (Central Apennines, Italy): Quaternary International, v. 267, p. 62-77, doi:10.1016/j.quaint.2011.03.020

Martens, K., 1992, A reassessment of Paralimnocythere Carbonnel, 1965 (Crustacea, Ostracoda, Limnocytherinae), with a description of a new genus and two new species: Bulletin de l'Insitut Royale des Sciences Naturelles de Belgique: Biologie, v. 62, p. 125-128.

Medici, M.C., and Gliozzi, E., 2008, Preliminary data on the freshwater ostracods from the middle-late Pliocene Tiberino "palaeo-ancient lake" (Umbria, central Italy): Atti del Museo Civico di Storia Naturale di Trieste, v. 53 , p. $39-48$

Meisch, C., 2000, Freshwater Ostracoda of Western and Central Europe, in Brauer, A., ed., Süsswasserfauna von Mitteleuropa 8: Crustacea-1, 3. Ostracoda: Heidelberg, Germany, Spektrum Akademischer Verlag, 522 p.

Meletti, C., and Montaldo, V., 2007, Stime di pericolosità sismica per diverse probabilità di superamento in 50 
anni: valori di ag. Progetto Dipartimento di Protezione Civile (DPC), Istituto Nazionale di Geofisica e Vulcanologia (INGV) S1, Deliverable D2, Milano, Italy. http://esse1.mi.ingv.it/d2.html (accessed April 2017).

Messina, P., Moro, M., and Speranza, F., 2001, Primi risultati di stratigrafia magnetica su alcune formazioni continentali dell'alta Valle dell'Aterno (Italia centrale): Il Quaternario, v. 14, p. 167-172.

Miccadei, E., Barberi, R., and Cavinato, G.P., 1998, La geologia quaternaria della Conca di Sulmona (Abruzzo, Italia centrale): Geologica Romana, v. 34, p. 59-86.

Miccadei, E., Piacentini, T., and Barberi, R., 2002, Uplift and local tectonic subsidence in the evolution of intramontane basins: The example of the Sulmona Basin (Central Apennines, Italy), in Dramis, F., Farabollini, P., and Molin, P., eds., Large-Scale Vertical Movements and Related Gravitational Processes. International Workshop Camerino-Rome, 21-26 June, 1999 Camerino, Italy, Studi Geologici Camerti, p. 119-134.

Milankovitch, M. 1941, Kanon der Erdbestrahlung und seine Anwendung auf das Eiszeitenproblem: Belgrade, Serbia, Royal Serbian Academy, Section of Mathematical and Natural Sciences, $633 \mathrm{p}$

Napoleone, G., Albianelli, A., Azzaroli, A., Bertini, A., Magi, M., and Mazzini, M., 2003, Calibration of the Upper Valdarno Basin to the Plio-Pleistocene for correlating the Apennine continental sequences: Il Quaternario, v. 16, p. 131-166.

Palombo, M.R., 2009, Biochronology of terrestrial mammals and Quaternary subdivisions: A case study of large mammals from the Italian peninsula: Il Quaternario, v. 22, p. 291-306.

Palombo, M.R., Mussi, M., Agostini, S., Barbieri, M., D Canzio, E., Di Rita, F., Fiore, I., Iacumin, P., Magri, D., Speranza, F., and Tagliacozzo, A., 2010, Human peopling of Italian intramontane basins: the early Middle Pleistocene site of Pagliare di Sassa (L'Aquila, central Italy): Quaternary International, v. 223-224, p. $170-178$.

Pascucci, V., Merlini, S., and Martini, I.P., 1999, Seismic stratigraphy of the Miocene-Pleistocene sedimentary basins of the Northern Tyrrhenian Sea and western Tuscany (Italy): Basin Research, v. 11, p. 337-356, doi:10.1046/j.1365-2117.1999.00104.x.

Patacca, E., and Scandone, P., 1989, Post-Tortonian mountain building in the Apennines. The role of the passive sinking of a relic lithospheric slab, in Boriani, A. Bonafede, M., Piccardo, G.B., and Vai, G.B., eds., The Lithosphere in Italy: Atti dei Convegni Lincei, v. 80, p. 157-176.

Patacca, E., Sartori, R., and Scandone, P., 1992, Tyrrhenian basin and Apenninic arcs: Kinematic relations since late Tortonian times: Memorie della Societa Geologica Italiana, v. 45, p. 425-451.

Patacca, E., Scandone, P., Di Luzio, E., Cavinato, G.P., and Parotto, M., 2008, Structural architectures of the Central Apennines: Interpretation of the CROP 11 seismic profile from the Adriatic coast to the orographic divide: Tectonics, v. 27, TC3006, doi:10.1029/2005TC001917.
Petronio, C., and Pandolfi, L., 2011, First occurrence of the genus Arvernoceros Heintz, 1970 from the late early Pleistocene of Italy: Rivista Italiana di Paleontologia e Stratigrafia, v. 117, p. 501-508.

Piacentini, T., and Miccadei, E., 2014, The role of drainage systems and intermontane basins in the Quaternary landscape of the Central Apennines chain (Italy): Rendiconti Lincei-Scienze Fisiche e Naturali, v. 25, p. 139-150, doi:10.1007/s12210-014-0312-2.

Pierson, T.C., and Costa, J.E., 1987, A rheologic classification of subaerial sediment-water flows, in Costa, J.E., and Wieczorek, G.F., eds., Debris Flows/Avalanches: Process, Recognition, and Mitigation: Geological Society of America Reviews in Engineering Geology, v. 7 , p. $1-12$.

Pucci, S., Mirabella, F., Pazzaglia, F., Barchi, M.R., Melelli, L., Tuccimei, P., Soligo, M., and Saccucci, L., 2014 nteraction between regional and local tectonic forcing along a complex Quaternary extensional basin: Upper Tiber Valley, Northern Apennines, Italy: Quaternary Science Reviews, v. 102, p. 111-132, doi:10.1016/j quascirev.2014.08.009.

Sardella, R., Angelone, C., Barisone, G., Bedetti, C., Di Canzio, E., Marcolini, F., and Squazzini, E., 2003, Italian Plio-Pleistocene mammal biochronology and correlation with marine sequences: Three case studies: Il Quaternario, v. 16, p. 15-20.

Sars, G.O., 1887, Nye betrag til kundskaben om middelhavets invertebratfauna: 4. Ostracoda Mediterranea (Sydeuropaeiske Ostracoder): Archiv dor Mathematic og Narurvidenskab, v. 12, p. 173-324.

Sars, G.O., 1890, Oversight af norges crustaceer med forelobige bamaerkninger over de nye eller mindre bekjendte arter: 2 (Branchiopoda, Ostracoda, Cirripedia): Forhandlinger i Christiania Videnskabs-Selskabet 1890 , p. $1-80$.

Scholz, C.H., and Campos, J., 1995, On the mechanism of seismic decoupling and back arc spreading at subduction zones: Journal of Geophysical Research, v. 100, p. 22,103-22,115, doi:10.1029/95JB01869.

Scognamiglio, L., Tinti, E., Michelini, A., Dreger, D.S., Cirella, A., Cocco, M., Mazza, S., and Piatanesi, A., 2010, Fast determination of moment tensors and rupture history: What has been learned from 6 April 2009 L'Aquila earthquake sequence: Seismological Research Letters, v. 81, p. 892-906, doi:10.1785/ gssrl.81.6.892.

Siori, M.S., Boero, A., Carnevale, G., Colombero, S., Delfino, M., Sardella, R., and Pavia, M., 2014, New data on early Pleistocene vertebrates from Monte Argentario (central Italy): Paleoecological and biochronological implications: Geobios, v. 47, p. 403-418, doi:10.1016/j.geobios.2014.10.001.

Spadi, M., Gliozzi, E., Cosentino, D., and Nocentini, M. 2016, Late Piacenzian-Gelasian freshwater ostracods (Crustacea) from L'Aquila Basin (central Apennines, Italy): Journal of Systematic Palaeontology, v. 14, p. 617-642, doi:10.1080/14772019.2015.1079561.

Spadi, M., Gliozzi, E., and Medici, C., 2017, A PlioPleistocene Caspiocypris species flock (Candoninae,
Ostracoda) from the palaeolake Tiberino (Umbria, central Italy): Journal of Systematic Palaeontology, http:// dx.doi.org/10.1080/14772019.2017.1310143.

Storti, F., Aldega, L., Balsamo, F., Corrado, S., Del Monaco, F., Di Paolo, L., Mastalertz, M., Monaco, P., and Tallini, M. 2013, Evidence for strong middle Pleistocene earthquakes in the epicentral area of the 6 April 2009 L'Aquila seismic event from sediment paleofluidization and overconsolidation: Journal of Geophysical Research-Solid Earth, v. 118, p. 3767-3784, doi:10.1002/ jgrb.50254.

Tallini, M., Cavuoto, G., Del Monaco, F., Di Fiore, V., Mancini, M., Caielli, G., Cavinato, G.P., De Franco, R. Pelosi, N., and Rapolla, A., 2012, Seismic surveys integrated with geological data for in-depth investigation of Mt. Pettino active fault area (western L'Aquila Basin): Italian Journal of Geosciences, v. 132, p. 389-402.

Uyeda, S., and Kanamori, H., 1979, Back-arc opening and the model of subduction: Journal of Geophysical Research, v. 84, no. B3, p. 1049-1061, doi:10.1029/ JB084iB03p01049.

van Hinsbergen, D.J.J., Hafkenscheid, E., Spakman, W. Meulenkamp, J.E., and Wortel, R., 2005, Nappe stack ing resulting from subduction of oceanic and continental lithosphere below Greece: Geology, v. 33, p. 325-328, doi:10.1130/G20878.1.

Vannoli, P., Burrato, P., Fracassi, U., and Valensise, G., 2012, A fresh look at the seismotectonics of the Abruzzi (Central Apennines) following the 6 April 2009 L'Aquila earthquake (Mw 6.3): Italian Journal of Geosciences, v. 131, p. 309-329.

Vezzani, L., and Ghisetti, F., 1998, Carta Geolog ica dell'Abruzzo, Regione Abruzzo, Settore Urbanistica-Beni Ambientali e Cultura: Firenze, Italy, Società Elaborazioni Cartografiche (SELCA), scale 1:100,000.

Vezzani, L., Ghisetti, F. and Festa, A., 2009, Caratteriz zazione strutturale dei principali sistemi di faglie dell'Abruzzo Aquilano: Geoitalia, v. 28, p. 4-12.

Wegmann, K.W., and Pazzaglia, F.J., 2009, Late Quaternary fluvial terraces of the Romagna and Marche Apennines, Italy: Climatic, lithologic and tectonic control on terrace genesis in an active orogen: Quaternary Science Reviews, v. 28, p. 137-165, doi:10.1016/j .quascirev.2008.10.006

Welther-Schultes, F., 2012, European Non-Marine Molluscs: A Guide for Species Identification: Göttingen, Germany, Planet Poster Edition, 760 p.

SCIENCE EdITOR: DAVID I. SCHOFIELD

Associate Editor: Brian R. Pratt

ManUsCRiPT Received 17 October 2016

Revised Manuscript Received 3 March 2017

MANUSCRIPT ACCEPTED 1 MAY 2017

Printed in the USA 